Keywords: High Level Waste

Supernate

Plutonium

Neptunium

Uranium

Ion exchange

Retention: Permanent

\title{
Review of Experimental Studies Investigating the Rate of Strontium and Actinide Adsorption by Monosodium Titanate
}

D. T. Hobbs

October 2010

Savannah River National Laboratory Savannah River Nuclear Solutions Aiken, SC 29808

Prepared for the U.S. Department of Energy under contract number DE-AC09-08SR22470.

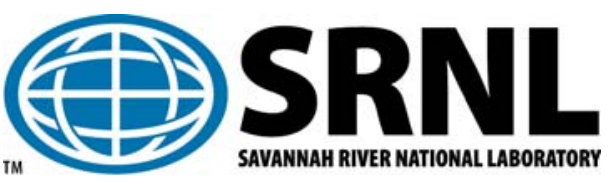




\section{DISCLAIMER}

This work was prepared under an agreement with and funded by the U.S. Government. Neither the U.S. Government or its employees, nor any of its contractors, subcontractors or their employees, makes any express or implied:

1. warranty or assumes any legal liability for the accuracy, completeness, or for the use or results of such use of any information, product, or process disclosed; or

2. representation that such use or results of such use would not infringe privately owned rights; or

3. endorsement or recommendation of any specifically identified commercial product, process, or service.

Any views and opinions of authors expressed in this work do not necessarily state or reflect those of the United States Government, or its contractors, or subcontractors.

\section{Printed in the United States of America \\ Prepared for \\ U.S. Department of Energy}




\section{REVIEWS AND APPROVALS}

AUTHORS:

D. T. Hobbs, Separations and Actinide Science Programs

Date

TECHNICAL REVIEW:

K. M. L. Taylor-Pashow, Separations and Actinide Science Programs

Date

APPROVAL:

S. D. Fink, Manager

Date

Separations and Actinide Science Programs

F. M. Pennebaker, Manager

Date

E\&CPT Research Programs

S.L. Marra, Manager

Date

E\&CPT Research Programs

T. H. Huff, Manager

Date

SCIX Design Authority Engineering 


\section{EXECUTIVE SUMMARY}

A number of laboratory studies have been conducted to determine the influence of mixing and mixing intensity, solution ionic strength, initial sorbate concentrations, temperature, and monosodium titanate (MST) concentration on the rates of sorbate removal by MST in high-level nuclear waste solutions. Of these parameters, initial sorbate concentrations, ionic strength, and MST concentration have the greater impact on sorbate removal rates. The lack of a significant influence of mixing and mixing intensity on sorbate removal rates indicates that bulk solution transport is not the rate controlling step in the removal of strontium and actinides over the range of conditions and laboratory-scales investigated. However, bulk solution transport may be a significant parameter upon use of MST in a 1.3 million-gallon waste tank such as that planned for the Small Column Ion Exchange (SCIX) program. Thus, Savannah River National Laboratory (SRNL) recommends completing the experiments in progress to determine if mixing intensity influences sorption rates under conditions appropriate for this program. Adsorption models have been developed from these experimental studies that allow prediction of strontium ( $\mathrm{Sr}$ ), plutonium $(\mathrm{Pu})$, neptunium $(\mathrm{Np})$ and uranium $(\mathrm{U})$ concentrations as a function of contact time with MST. Fairly good agreement has been observed between the predicted and measured sorbate concentrations in the laboratory-scale experiments. 


\section{TABLE OF CONTENTS}

LIST OF FIGURES

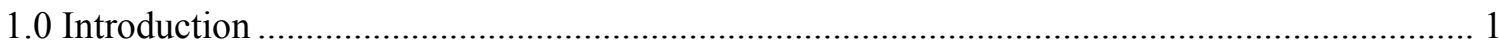

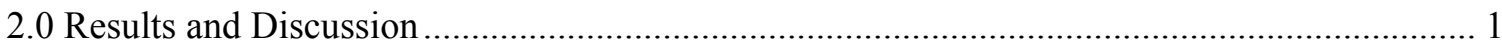

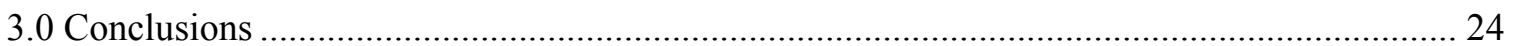

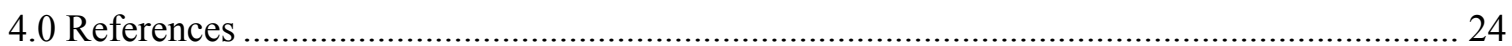

Appendix A. Test Conditions and Initial Sorbate Concentrations for Adsorption Rate Tests ..... 25 


\section{LIST OF FIGURES}

Figure 1. Strontium Concentration Changes with Time upon Contact of $6.0 \mathrm{M}$ Na High Activity Salt Solution with $1.1 \mathrm{~g} / \mathrm{L}$ MST

Figure 2. Strontium Concentration Changes with Time upon Contact of 6.0 M Na Low Activity Salt Solution with $1.1 \mathrm{~g} / \mathrm{L}$ MST

Figure 3. Plutonium Concentration Changes with Time upon Contact of $6.0 \mathrm{M} \mathrm{Na}$ High Activity Salt Solution with $1.1 \mathrm{~g} / \mathrm{L}$ MST 5

Figure 4. Plutonium Concentration Changes with Time upon Contact of 6.0 M Na Low Activity Salt Solution with $1.1 \mathrm{~g} / \mathrm{L}$ MST

Figure 5. Neptunium Concentration Changes with Time upon Contact of 6.0 M Na High Activity Salt Solution with $1.1 \mathrm{~g} / \mathrm{L}$ MST

Figure 6. Neptunium Concentration Changes with Time upon Contact of 6.0 M Na Low Activity Salt Solution with $1.1 \mathrm{~g} / \mathrm{L}$ MST

Figure 7. Uranium Concentration Changes with Time upon Contact of $6.0 \mathrm{M}$ Na High Activity Salt Solution with $1.1 \mathrm{~g} / \mathrm{L}$ MST

Figure 8. Uranium Concentration Changes with Time upon Contact of $6.0 \mathrm{M} \mathrm{Na}$ Low Activity Salt Solution with $1.1 \mathrm{~g} / \mathrm{L}$ MST ......

Figure 9. Comparison of Stirred and Agitated Mixing Conditions for the Removal of Strontium and Plutonium

Figure 10. Comparison of Stirred and Agitated Mixing Conditions for the Removal of Neptunium.

Figure 11. Strontium Concentration versus Time upon Contact of a 4.5 M Na Salt Solution Containing $90 \mu \mathrm{g} / \mathrm{L} \mathrm{Sr}$ with 0.2 or $0.4 \mathrm{~g} / \mathrm{L}$ MST at $25{ }^{\circ} \mathrm{C}$ with Mixing Provided by Orbital Shaker at $200 \mathrm{rpm}$.

Figure 12. Plutonium Concentration versus Time upon Contact of a $4.5 \mathrm{M} \mathrm{Na}$ Salt Solution Containing $63.5 \mu \mathrm{g} / \mathrm{L} \mathrm{Pu}$ with 0.2 or $0.4 \mathrm{~g} / \mathrm{L}$ MST at $25{ }^{\circ} \mathrm{C}$ with Mixing Provided by Orbital Shaker at $200 \mathrm{rpm}$. 15

Figure 13. Neptunium Concentration versus Time upon Contact of a 4.5 M Na Salt Solution Containing $406 \mu \mathrm{g} / \mathrm{L} \mathrm{Np}$ with 0.2 or $0.4 \mathrm{~g} / \mathrm{L} \mathrm{MST}$ at $25{ }^{\circ} \mathrm{C}$ with Mixing Provided by Orbital Shaker at $200 \mathrm{rpm}$. 15

Figure 14. Uranium Concentration versus Time upon Contact of a $4.5 \mathrm{M} \mathrm{Na}$ Salt Solution Containing $9,020 \mu \mathrm{g} / \mathrm{L} \mathrm{U}$ with 0.2 or $0.4 \mathrm{~g} / \mathrm{L}$ MST at $25{ }^{\circ} \mathrm{C}$ with Mixing Provided by Orbital Shaker at $200 \mathrm{rpm}$.

Figure 15. Comparison of Strontium Removal by MST in Actual and Simulated Tank Waste Solution 14

Figure 16. Comparison of Plutonium Removal by MST in Actual and Simulated Tank Waste Solutions. 15 
Figure 17. Comparison of Neptunium Removal by MST in Actual and Simulated Tank Waste Solutions.

Figure 18. Strontium Decontamination Factor versus Time in Simulated and Actual Tank Waste Solutions at Various Sodium Concentrations upon Contact with $0.2 \mathrm{~g} / \mathrm{L}$ MST .

Figure 19. Plutonium Decontamination Factor versus Time in Simulated and Actual Tank Waste Solutions at Various Sodium Concentrations upon Contact with $0.2 \mathrm{~g} / \mathrm{L} \mathrm{MST}$. 17

Figure 20. ${ }^{90} \mathrm{Sr}$ Activity versus Time in Tank 37H/44F Waste Solution upon Contact with 0.52 $\mathrm{g} / \mathrm{L}$ MST. Data points identified as "Walker" represent those measured during the testing. The data points identified as "Peters" represent analysis of archived samples at a later date. 18

Figure 21. Plutonium Activity versus Time in Tank 37H/44F Waste Solution upon Contact with $0.52 \mathrm{~g} / \mathrm{L}$ MST. Data points identified as "Walker" represent those measured during the testing. The data points identified as "Peters" represent analysis of archived samples at a later date.

Figure 22. ${ }^{90} \mathrm{Sr}$ Activity versus Time in Tank $37 \mathrm{H}$ Waste Solution upon Contact with $0.40 \mathrm{~g} / \mathrm{L}$ MST

Figure 23. ${ }^{85} \mathrm{Sr}$ Activity versus Time for the Spiked Tank 37H/44F Waste Solution at upon Contact with $0.40 \mathrm{~g} / \mathrm{L}$ MST

Figure 24. Pu Activity versus Time for the Spiked Tank 37H/44F Waste Solution at upon Contact with $0.40 \mathrm{~g} / \mathrm{L}$ MST .....

Figure 25. Sr loading on MST at $[\mathrm{Na}]=6 \mathrm{M}, \mathrm{T}=25^{\circ} \mathrm{C}$ and $0.2 \mathrm{~g} / \mathrm{L}$ MST ............................. 22

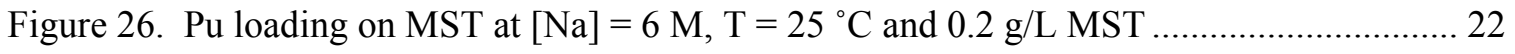

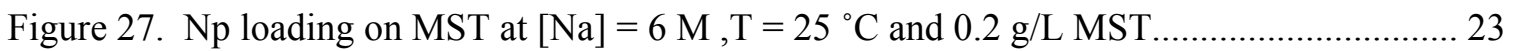

Figure 28. U loading on MST at $[\mathrm{Na}]=6 \mathrm{M}, \mathrm{T}=25^{\circ} \mathrm{C}$ and $0.2 \mathrm{~g} / \mathrm{L} \mathrm{MST}$ 23 


\section{LIST OF ABBREVIATIONS}

$\begin{array}{ll}\text { ARP } & \text { Actinide Removal Process } \\ \text { CSSX } & \text { Caustic Side Solvent Extraction } \\ \text { DA } & \text { Dubinin-Astashov } \\ \text { DF } & \text { decontamination factor } \\ \text { HLW } & \text { High Level Waste } \\ \text { ITP } & \text { In-Tank Precipitation } \\ \text { MST } & \text { monosodium titanate } \\ \text { Np } & \text { neptunium } \\ \text { Pu } & \text { plutonium } \\ \text { SCIX } & \text { Small Column Ion Exchange } \\ \text { Sr } & \text { strontium } \\ \text { SRNL } & \text { Savannah River National Laboratory } \\ \text { SRS } & \text { Savannah River Site } \\ \text { U } & \text { uranium }\end{array}$




\subsection{Introduction}

MST is an effective ion-exchange material for the removal of strontium and actinides from strongly alkaline and high ionic-strength salt solutions such as the high-level waste (HLW) stored at the Savannah River Site (SRS). MST was first selected for use at SRS in the early 1980s principally for the removal of ${ }^{90} \mathrm{Sr}$. Early testing indicated that MST was also effective for the removal of alpha-activity in the waste solutions. However, it was not until more extensive characterization of the SRS waste that the removal of alpha activity was of increased importance, principally due to plutonium isotopes from the production of weapons grade $\mathrm{Pu}\left({ }^{239 / 240} \mathrm{Pu}\right)$ and heat source $\mathrm{Pu}\left({ }^{238} \mathrm{Pu}\right)$. Furthermore, the disposition of larger quantities of ${ }^{237} \mathrm{~Np}$ to the HLW system also added an increased need to be able to remove this isotope. Uranium removal is not a high need given the low specific activity of the common uranium isotopes found in SRS waste. However, the quantity of uranium in HLW is much higher than any of the other isotopes and, therefore, removal of uranium by MST can impact the performance of MST to remove the other, more problematic, radionuclides.

MST was planned to be added to the strike tank used for the In-Tank Precipitation (ITP) process. In the ITP process, MST would be added to the waste solution diluted to a sodium concentration of $4.5 \mathrm{M}$ at $25^{\circ} \mathrm{C}$ in a Type III waste tank equipped with mixing pumps. The contact time in the batch contact process would be a minimum of two weeks. Laboratory testing under these conditions indicated that this was sufficient time for the system to reach near steady-state conditions. Thus, adsorption rate was not considered a significant constraint on ITP throughput.

After the ITP process was abandoned in 1998, a number of alternate materials and methods for selective strontium and actinide removal were evaluated as part of the Alternative Salt Disposition Studies. In 2001, a batch contact method using MST was selected as the preferred method to remove ${ }^{90} \mathrm{Sr}$ and alpha-emitting radionuclides from SRS waste solutions. However, the rate of adsorption became a much more important issue in achieving the necessary volumetric throughput in alternative salt disposition flowsheets. Characterization of saltcake and supernate wastes also indicated the need to investigate MST performance at higher initial concentrations of total strontium and plutonium.

Facility designs and downstream operational impacts have also impacted the planned concentrations of MST in treatment facilities. Thus, a number of bench-scale experiments with both simulated and tank waste solutions have been carried out since 1998 to measure sorbate removal rates under a variety of testing conditions. This work culminated in developing adsorption isotherm models with corresponding kinetic terms for each of the major sorbates upon batch contact with MST. This document summarizes the findings of these studies.

\subsection{Results and Discussion}

Ion-Exchange Mechanism and Kinetics

Sodium titanates serve as cation ion-exchangers by which sodium cations $\left(\mathrm{Na}^{+}\right)$are exchanged for other cations. For example, a dication such as $\mathrm{Sr}^{2+}$ or $\mathrm{UO}_{2}{ }^{2+}$ would be exchanged for two $\mathrm{Na}^{+}$ cations to maintain charge neutrality. Neptunium, present as the monocation, $\mathrm{NpO}_{2}^{+}$, and plutonium, present as $\mathrm{Pu}^{4+}$, would be exchanged for one $\mathrm{Na}^{+}$and four $\mathrm{Na}^{+}$cations, respectively.

In the complex waste solutions, strontium and actinides exist as multiple chemical species. For example, strontium is reported to exist as a dication, $\mathrm{Sr}^{2+}$, a monohydroxy cation, $\operatorname{Sr}(\mathrm{OH})^{+}$, and the dihydroxy, neutral species, $\operatorname{Sr}(\mathrm{OH})_{2}$, in strongly alkaline aqueous solutions. In strongly alkaline solutions, the actinides are reported to be present as neutral or anionic hydroxy 
complexes such as $\mathrm{UO}_{2}(\mathrm{OH})_{2}, \mathrm{UO}_{2}(\mathrm{OH})_{3}{ }^{-}$, and $\mathrm{UO}_{2}(\mathrm{OH})_{4}{ }^{2-}$ for uranium and $\mathrm{Pu}(\mathrm{OH})_{4}, \mathrm{Pu}(\mathrm{OH})_{5}{ }^{-}$, and $\mathrm{Pu}(\mathrm{OH})_{6}{ }^{2-}$ for plutonium. In solutions with high carbonate concentrations, the actinides could also be present as mixed hydroxy-carbonato complexes such as $\mathrm{UO}_{2}(\mathrm{OH})_{2}\left(\mathrm{CO}_{3}\right)^{2-}$ and $\mathrm{UO}_{2}(\mathrm{OH})_{2}\left(\mathrm{CO}_{3}\right)_{2}{ }^{4-}$. Multi-nuclear species are also possible. Examples of multi-nuclear species include the uranyl hydroxide dimer, $\left[\mathrm{UO}_{2}(\mathrm{OH})_{3}\right]_{2}{ }^{2-}$, and plutonium polymer, $\left(\mathrm{PuO}_{2}\right)_{\mathrm{x}}$. Thus, a complete description of ion-exchange chemistry involves multiple chemical species for each sorbate. Examples of possible reaction chemistry are shown below for strontium and plutonium.

$$
\begin{aligned}
& \mathrm{Sr}^{2+}+2 \mathrm{NaTi}_{2} \mathrm{O}_{5} \mathrm{H}=\mathrm{Sr}\left(\mathrm{OTi}_{2} \mathrm{O}_{4} \mathrm{H}\right)_{2}+2 \mathrm{Na}^{+} \\
& \mathrm{Sr}(\mathrm{OH})^{+}+\mathrm{NaTi}_{2} \mathrm{O}_{5} \mathrm{H}=(\mathrm{OH}) \mathrm{SrOTi}_{2} \mathrm{O}_{4} \mathrm{H}+\mathrm{Na}^{+} \\
& \mathrm{Sr}(\mathrm{OH})_{2}+\mathrm{NaTi}_{2} \mathrm{O}_{5} \mathrm{H}=(\mathrm{OH}) \mathrm{SrOTi}_{2} \mathrm{O}_{4} \mathrm{H}+\mathrm{Na}^{+}+\mathrm{OH}^{-} \\
& \mathrm{Sr}(\mathrm{OH})_{2}+2 \mathrm{NaTi}_{2} \mathrm{O}_{5} \mathrm{H}=\mathrm{Sr}\left(\mathrm{OTi}_{2} \mathrm{O}_{4} \mathrm{H}\right)_{2}+2 \mathrm{Na}^{+}+2 \mathrm{OH}^{-} \\
& \mathrm{Pu}^{4+}+4 \mathrm{NaTi}_{2} \mathrm{O}_{5} \mathrm{H}=\mathrm{Pu}\left(\mathrm{OTi}_{2} \mathrm{O}_{4} \mathrm{H}\right)_{4}+4 \mathrm{Na}^{+} \\
& \mathrm{Pu}(\mathrm{OH})_{4}+\mathrm{NaTi}_{2} \mathrm{O}_{5} \mathrm{H}=(\mathrm{OH})_{3} \mathrm{PuOTi}_{2} \mathrm{O}_{4} \mathrm{H}+\mathrm{Na}^{+}+\mathrm{OH}^{-} \\
& \mathrm{Pu}(\mathrm{OH})_{4}+2 \mathrm{NaTi}_{2} \mathrm{O}_{5} \mathrm{H}=(\mathrm{OH})_{2} \mathrm{Pu}\left(\mathrm{OTi}_{2} \mathrm{O}_{4} \mathrm{H}\right)_{2}+2 \mathrm{Na}^{+}+2 \mathrm{OH}^{-} \\
& \mathrm{Pu}(\mathrm{OH})_{4}+3 \mathrm{NaTi}_{2} \mathrm{O}_{5} \mathrm{H}=(\mathrm{OH}) \mathrm{Pu}\left(\mathrm{OTi}_{2} \mathrm{O}_{4} \mathrm{H}\right)_{3}+3 \mathrm{Na}^{+}+3 \mathrm{OH}^{-} \\
& \mathrm{Pu}(\mathrm{OH})_{4}+4 \mathrm{NaTi}_{2} \mathrm{O}_{5} \mathrm{H}=\mathrm{Pu}\left(\mathrm{OTi} \mathrm{O}_{4} \mathrm{H}\right)_{4}+4 \mathrm{Na}^{+}+4 \mathrm{OH}^{-} \\
& \mathrm{Pu}(\mathrm{OH})_{5}^{-}+\mathrm{NaTi}_{2} \mathrm{O}_{5} \mathrm{H}=(\mathrm{OH})_{3} \mathrm{PuOTi}_{2} \mathrm{O}_{4} \mathrm{H}+\mathrm{Na}^{+}+2 \mathrm{OH}^{-} \\
& \mathrm{Pu}(\mathrm{OH})_{5}^{-}+2 \mathrm{NaTi}_{2} \mathrm{O}_{5} \mathrm{H}=(\mathrm{OH})_{2} \mathrm{Pu}\left(\mathrm{OTi}_{2} \mathrm{O}_{4} \mathrm{H}\right)_{2}+2 \mathrm{Na}^{+}+3 \mathrm{OH}^{-} \\
& \mathrm{Pu}(\mathrm{OH})_{5}^{-}+3 \mathrm{NaTi}_{2} \mathrm{O}_{5} \mathrm{H}=(\mathrm{OH}) \mathrm{Pu}\left(\mathrm{OTi}_{2} \mathrm{O}_{4} \mathrm{H}\right)_{3}+3 \mathrm{Na}^{+}+4 \mathrm{OH}^{-} \\
& \mathrm{Pu}(\mathrm{OH})_{5}^{-}+4 \mathrm{NaTi}_{2} \mathrm{O}_{5} \mathrm{H}=\mathrm{Pu}\left(\mathrm{OTi} \mathrm{O}_{4} \mathrm{O}_{4} \mathrm{H}_{4}+4 \mathrm{Na}^{+}+5 \mathrm{OH}^{-}\right.
\end{aligned}
$$

The general mechanism of ion exchange of chemical species dissolved in solution with a solid ion exchanger is a multiple step process. The first step is mass transfer or diffusion of ions from the bulk solution to a film surrounding the solid particle (interphase film). The second step is diffusion of ions in the interphase film to the solid phase. The third step is transfer of the ion through the boundary between the film and solid phase. A fourth step is diffusion of the ion through the particle. A fifth step would be the formation of ion pairs (e.g., $\mathrm{Sr}^{2+}$ with $\mathrm{TiO}_{6}{ }^{2-}$ ). In the case of the titanates, X-ray absorption fine structure analyses indicated that strontium and the actinides are coordinated to the oxygen atoms of the anionic titania. This fifth step would also include the release of bound water, hydroxide, or carbonate to afford coordination sites. To maintain charge neutrality a similar set of steps occurs in reverse for the exchanged cation (i.e., $\mathrm{Na}^{+}$in MST) as it leaves the ion exchanger and releases into the bulk solution.

The rate of this multiple step process will be controlled by the rate of the slowest step. Generally, the first step (mass transfer in bulk solution) is assisted by stirring or other forms of agitation. As such, bulk transport is generally not the rate limiting step in the ion exchange process. All of the remaining steps are controlled by the mobility of the ions in the particular phase. Note that agitation of the bulk solution can reduce the thickness of the interphase film, but cannot remove it completely. Reducing the thickness reduces the diffusion distance, which will increase the overall rate if interphase film diffusion is the rate limiting step.

\section{Experimental Findings}

As part of the Salt Disposition Alternatives evaluation, researchers at SRNL investigated the rate of strontium and actinides $(\mathrm{Pu}, \mathrm{Np}$ and $\mathrm{U})$ removal by MST from simulated waste solutions over a range of temperatures $\left(17-65^{\circ} \mathrm{C}\right)$ and sodium concentrations $(4.5-7.5 \mathrm{M}){ }^{1}$ In these tests $100-\mathrm{mL}$ aliquots of simulated waste solutions were contacted with MST at concentrations ranging from $0.2-2.0 \mathrm{~g} / \mathrm{L}$ and mixed for up to two weeks in a controlled-temperature waterbath equipped with an orbital shaker operating at $200 \mathrm{rpm}$. The mixing energy supplied by the orbital shaker suspends a small fraction of the MST particles within the solution. The bulk of the MST solids 
remain on and move along the bottom of the test bottle and lift up briefly off the bottom when they reach the side wall of the bottle. Additional test bottles were prepared and allowed to stand unagitated in the waterbath at the respective test temperature. The quiescent test bottles did receive agitation periodically to ensure a homogeneous mixture during each sampling event.

Figures $1-8$ provide graphs of the sorbate concentration $(\mu \mathrm{g} / \mathrm{L})$ versus time for the centerpoint subset set tests that were shaken and allowed to stand in the waterbath. The designation of "mixed" indicates that the test was conducted in an actively agitated or stirred condition. The designation of "unmixed" indicates that the test was not actively agitated or stirred except during each sampling event. Although the tests were carried out for up to 250 hours, the bulk of the adsorption occurs within the first five hours of contact. Thus, in Figures $1-8$, only the concentrations for the sampling events below five hours are plotted. This provides the best opportunity to measure differences in the rate of adsorption between the mixed and unmixed tests.

The salt solutions used in these tests were prepared to achieve a total sodium concentration of 6.0 M. All tests were contacted with $1.1 \mathrm{~g} / \mathrm{L}$ of MST. Appendix A provides a summary of the sodium concentrations, initial sorbate concentrations, MST concentration and temperature for these and other tests conducted to investigate the rates of sorbate adsorption by MST. Two levels of sorbate concentrations were tested and designated as high activity and low activity, respectively.

Table 1 provides the calculated minimum and maximum removal rates $(\mu \mathrm{g} / \mathrm{L} / \mathrm{h})$ for each sorbate in both the mixed and unmixed tests with the high activity and low activity solutions. The removal rate was calculated by subtracting the initial and measured sorbate concentrations and dividing by the sampling time for the first sampling event (approximately 2 hours). The minimum and maximum removal rates were calculated by subtracting or adding two times the standard deviation of the rates to the average rate determined from duplicate tests. For the high activity $6.0 \mathrm{M}$ sodium salt solution contacted with $1.1 \mathrm{~g} / \mathrm{L}$ of MST, the range of removal rates for the sorbates in the unmixed tests overlapped that for the continuously agitated tests except for the 45 and $65^{\circ} \mathrm{C}$ tests with strontium. At $45^{\circ} \mathrm{C}$, the unmixed removal rate measured slightly slower than that of the mixed case. At $65^{\circ} \mathrm{C}$, the unmixed removal rates measured slightly higher than the mixed tests. This same trend was also found for strontium, uranium, and neptunium in the low activity salt solution. In fact, the removal rates measured faster for all of the sorbates in the unmixed tests compared to the mixed tests at $65^{\circ} \mathrm{C}$ with the low activity salt solution. Given these findings, SRNL concludes that the mixing energy provided by the waterbath shaker did not enhance the rate of sorbate removal. 


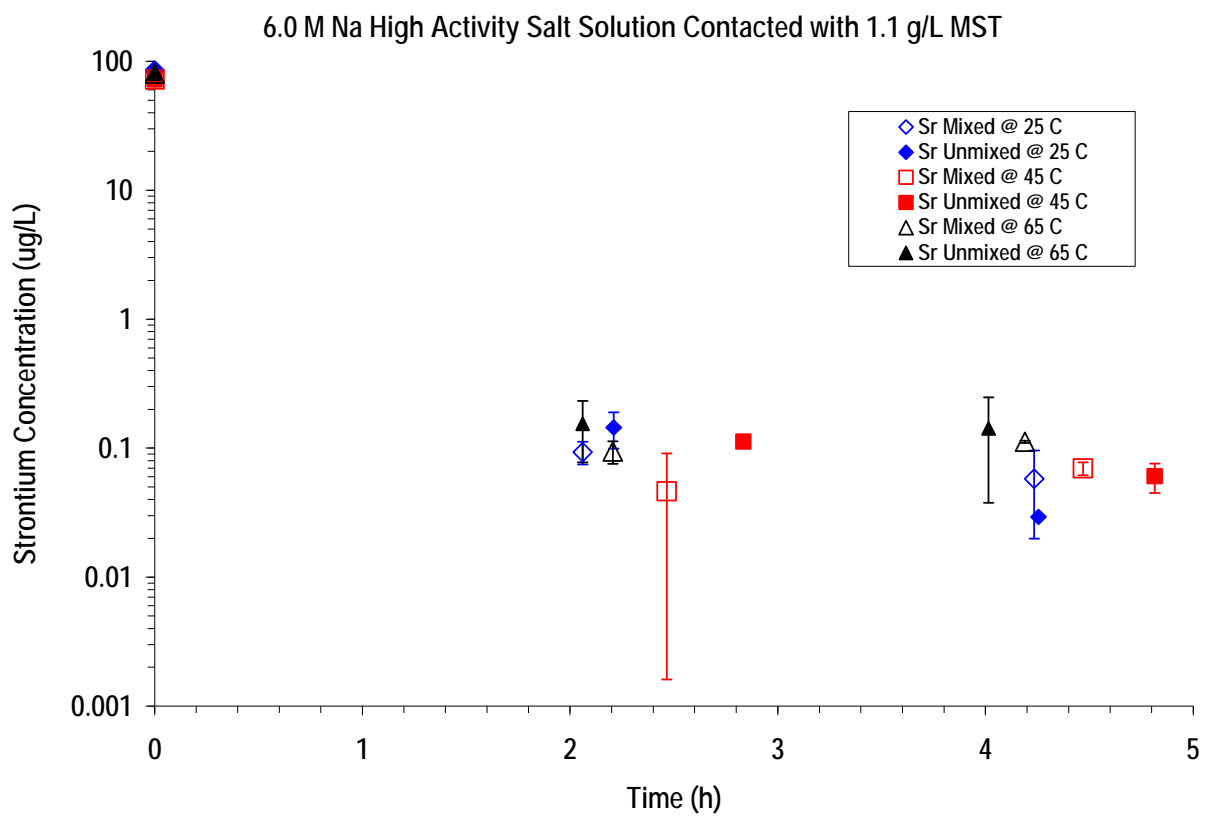

Figure 1. Strontium Concentration Changes with Time upon Contact of 6.0 M Na High Activity Salt Solution with $1.1 \mathrm{~g} / \mathrm{L}$ MST

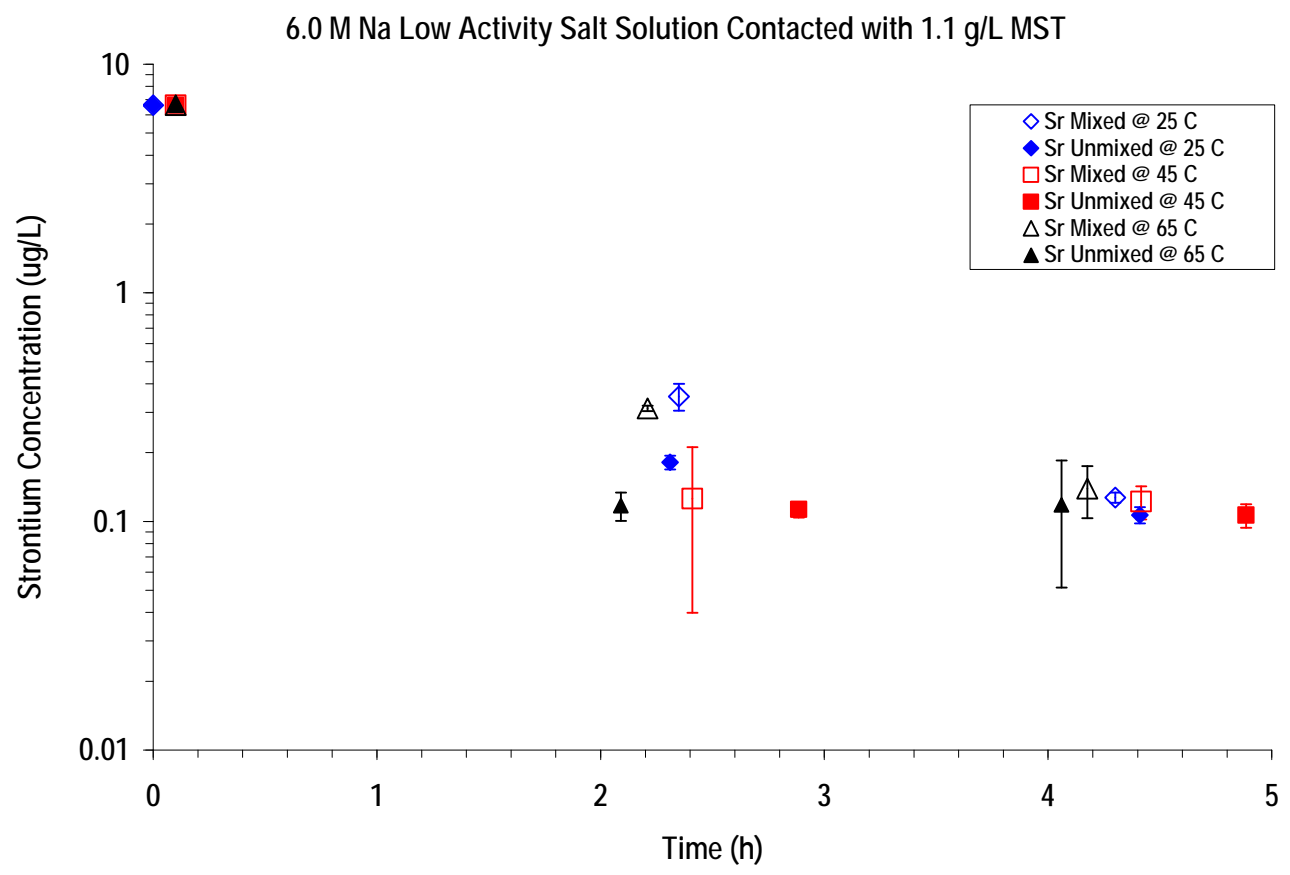

Figure 2. Strontium Concentration Changes with Time upon Contact of 6.0 M Na Low Activity Salt Solution with $1.1 \mathrm{~g} / \mathrm{L}$ MST 


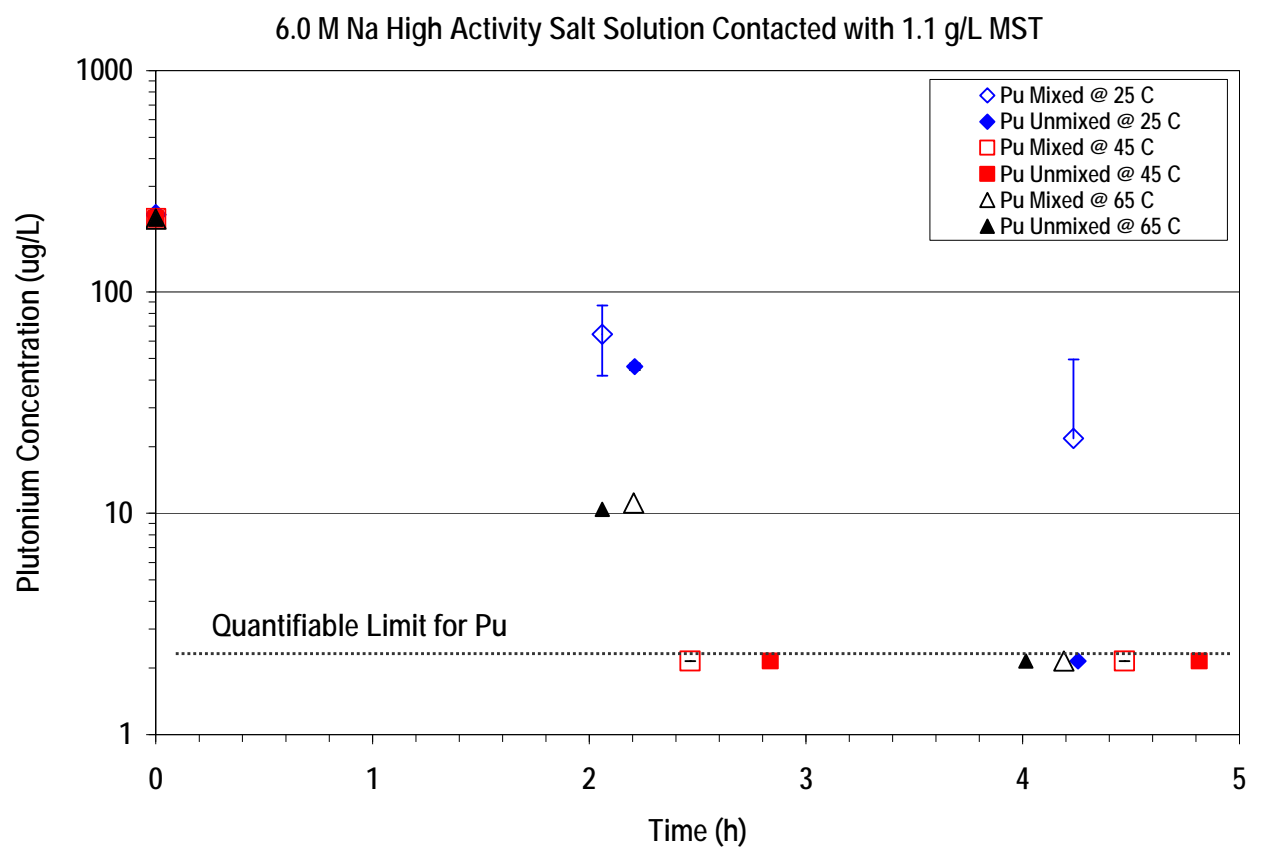

Figure 3. Plutonium Concentration Changes with Time upon Contact of 6.0 M Na High Activity Salt Solution with $1.1 \mathrm{~g} / \mathrm{L}$ MST

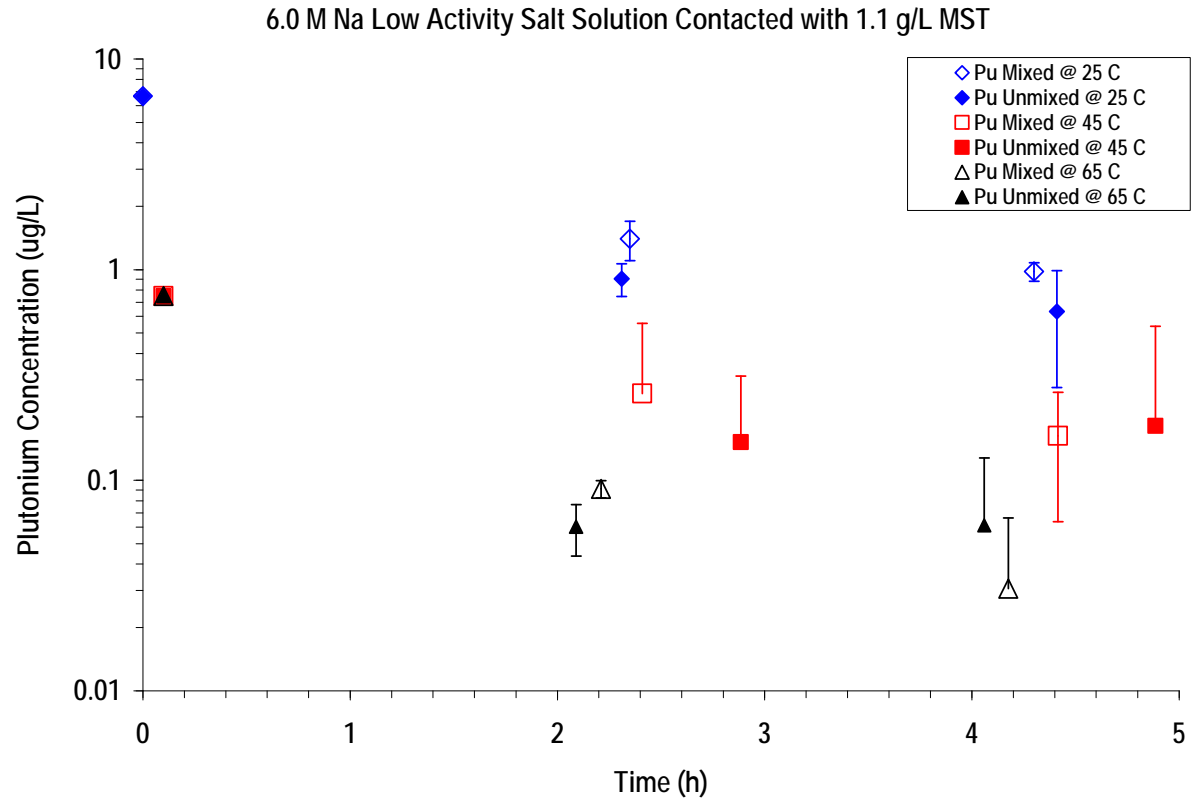

Figure 4. Plutonium Concentration Changes with Time upon Contact of 6.0 M Na Low Activity Salt Solution with $1.1 \mathrm{~g} / \mathrm{L}$ MST 


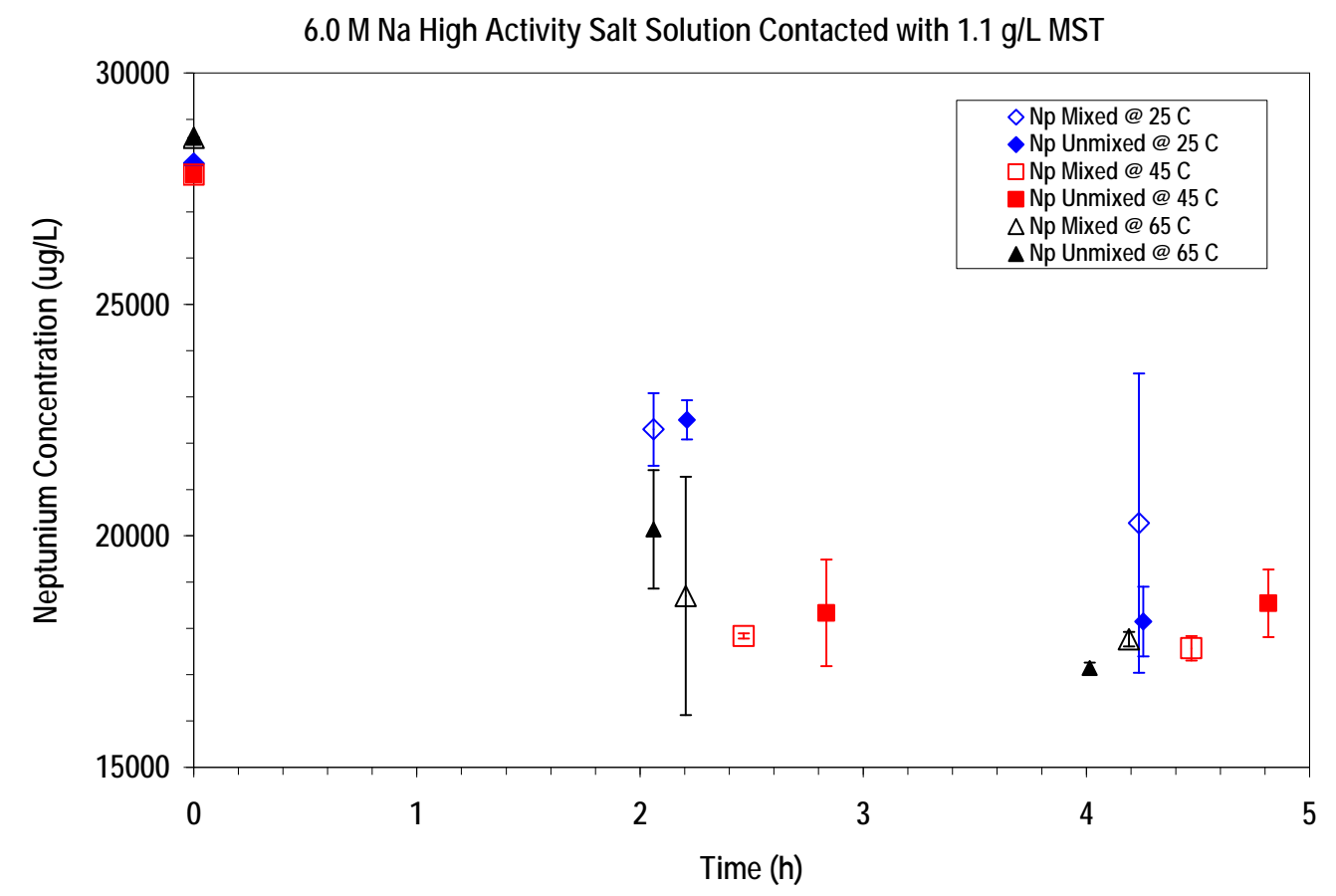

Figure 5. Neptunium Concentration Changes with Time upon Contact of 6.0 M Na High Activity Salt Solution with $1.1 \mathrm{~g} / \mathrm{L}$ MST

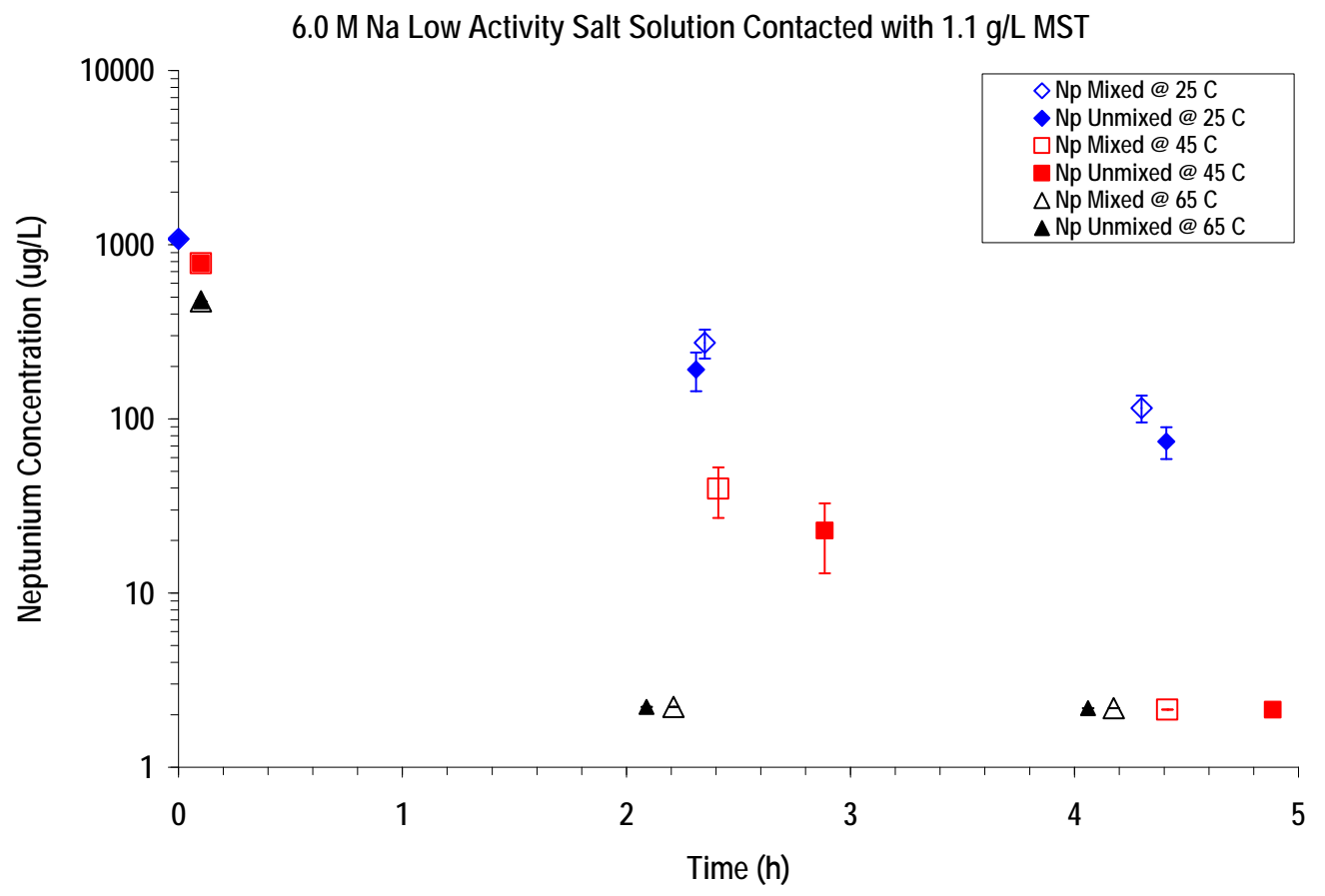

Figure 6. Neptunium Concentration Changes with Time upon Contact of 6.0 M Na Low Activity Salt Solution with $1.1 \mathrm{~g} / \mathrm{L}$ MST 


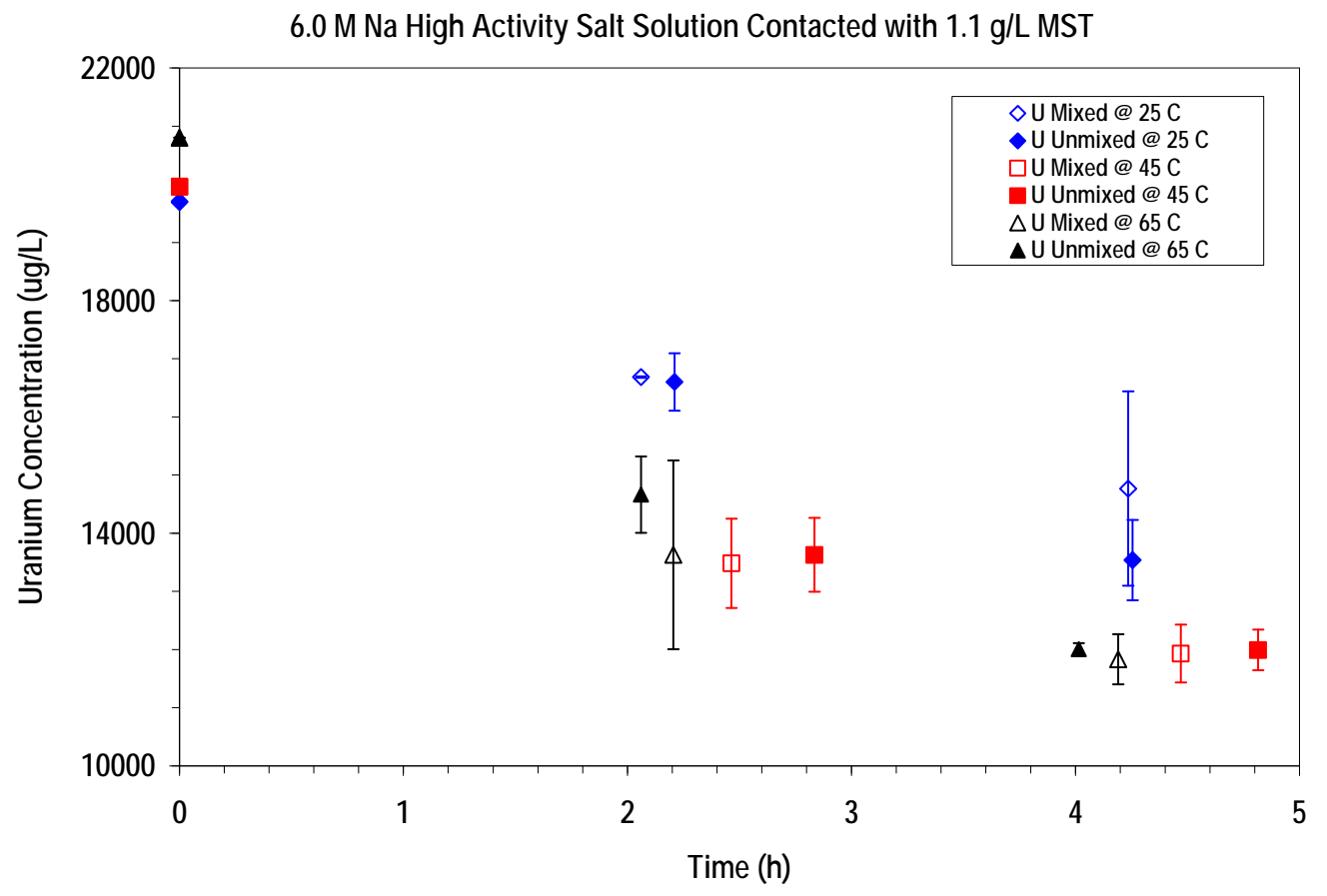

Figure 7. Uranium Concentration Changes with Time upon Contact of 6.0 M Na High Activity Salt Solution with $1.1 \mathrm{~g} / \mathrm{L}$ MST

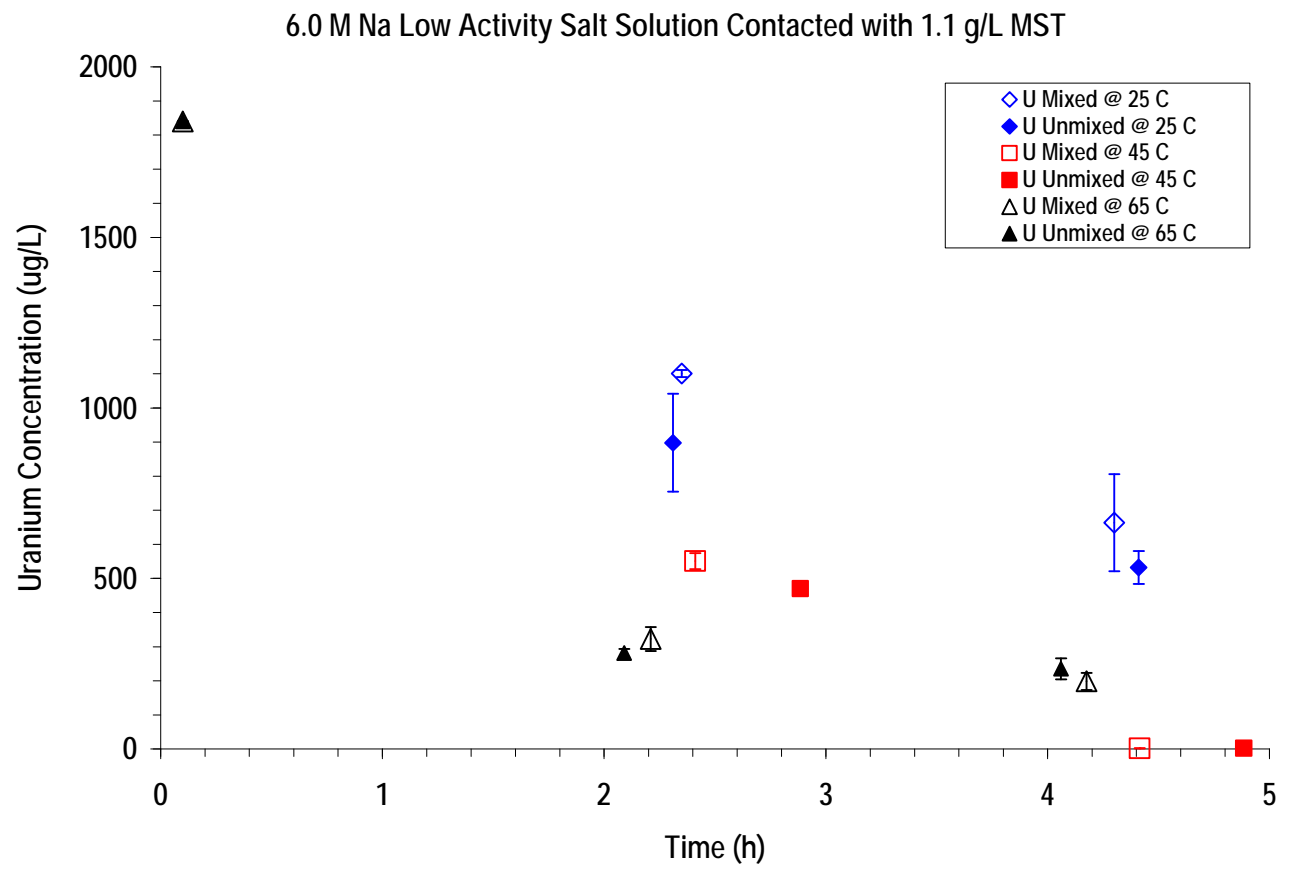

Figure 8. Uranium Concentration Changes with Time upon Contact of 6.0 M Na Low Activity Salt Solution with $1.1 \mathrm{~g} / \mathrm{L}$ MST 
Table 1. Calculated Minimum and Maximum Sorbate Removal Rates in a 6.0 M Na Salt Solution Contacted with $1.1 \mathrm{~g} / \mathrm{L}$ MST for Approximately Two Hours

\begin{tabular}{|c|c|c|c|c|c|c|c|c|c|}
\hline \multirow[b]{3}{*}{$\begin{array}{c}\text { Temperature } \\
\left({ }^{\circ} \mathrm{C}\right) \\
\end{array}$} & \multirow[b]{3}{*}{$\begin{array}{l}\text { Solution } \\
\text { Activity }\end{array}$} & \multicolumn{4}{|c|}{ Strontium } & \multicolumn{4}{|c|}{ Plutonium } \\
\hline & & \multicolumn{2}{|c|}{ Mixed } & \multicolumn{2}{|c|}{ Unmixed } & \multicolumn{2}{|c|}{ Mixed } & \multicolumn{2}{|c|}{ Unmixed } \\
\hline & & \begin{tabular}{|c|}
$\begin{array}{c}\text { Minimum Rate } \\
(\mathrm{ug} / \mathrm{L} / \mathrm{h})\end{array}$ \\
\end{tabular} & $\begin{array}{c}\text { Maximum } \\
\text { Rate }(\mathrm{ug} / \mathrm{L} / \mathrm{h})\end{array}$ & \begin{tabular}{|c|}
$\begin{array}{c}\text { Minimum Rate } \\
(\mathrm{ug} / \mathrm{L} / \mathrm{h})\end{array}$ \\
\end{tabular} & $\begin{array}{c}\text { Maximum } \\
\text { Rate }(\mathrm{ug} / \mathrm{L} / \mathrm{h})\end{array}$ & \begin{tabular}{|c|}
$\begin{array}{c}\text { Minimum Rate } \\
(\mathrm{ug} / \mathrm{L} / \mathrm{h})\end{array}$ \\
\end{tabular} & $\begin{array}{c}\text { Maximum } \\
\text { Rate }(\mathrm{ug} / \mathrm{L} / \mathrm{h})\end{array}$ & \begin{tabular}{|c|}
$\begin{array}{c}\text { Minimum Rate } \\
(\mathrm{ug} / \mathrm{L} / \mathrm{h})\end{array}$ \\
\end{tabular} & $\begin{array}{c}\text { Maximum } \\
\text { Rate }(\mathrm{ug} / \mathrm{L} / \mathrm{h})\end{array}$ \\
\hline 25 & High & 36.6 & 46.9 & 37.8 & 38.8 & 49.2 & 113.0 & 77.9 & 82.8 \\
\hline 45 & High & 29.2 & 29.3 & 25.4 & 25.4 & $>86.1$ & $>86.1$ & $>74.9$ & $>74.9$ \\
\hline 65 & High & 36.3 & 36.3 & 38.8 & 38.9 & $>86.1$ & $>86.1$ & $>98.5$ & $>98.5$ \\
\hline
\end{tabular}

\begin{tabular}{|c|c|c|c|c|c|c|c|c|c|}
\hline \multirow[b]{3}{*}{$\begin{array}{c}\text { Temperature } \\
\left({ }^{\circ} \mathrm{C}\right) \\
\end{array}$} & \multirow[b]{3}{*}{$\begin{array}{l}\text { Solution } \\
\text { Activity }\end{array}$} & \multicolumn{4}{|c|}{ Neptunium } & \multicolumn{4}{|c|}{ Uranium } \\
\hline & & \multicolumn{2}{|c|}{ Mixed } & \multicolumn{2}{|c|}{ Unmixed } & \multicolumn{2}{|c|}{ Mixed } & \multicolumn{2}{|c|}{ Unmixed } \\
\hline & & \begin{tabular}{|c|}
$\begin{array}{c}\text { Minimum Rate } \\
(\mathrm{ug} / \mathrm{L} / \mathrm{h})\end{array}$ \\
\end{tabular} & $\begin{array}{c}\text { Maximum } \\
\text { Rate }(\mathrm{ug} / \mathrm{L} / \mathrm{h})\end{array}$ & \begin{tabular}{|c|}
$\begin{array}{c}\text { Minimum Rate } \\
(\mathrm{ug} / \mathrm{L} / \mathrm{h})\end{array}$ \\
\end{tabular} & $\begin{array}{c}\text { Maximum } \\
\text { Rate }(\mathrm{ug} / \mathrm{L} / \mathrm{h})\end{array}$ & \begin{tabular}{|c|}
$\begin{array}{c}\text { Minimum Rate } \\
(\mathrm{ug} / \mathrm{L} / \mathrm{h})\end{array}$ \\
\end{tabular} & $\begin{array}{c}\text { Maximum } \\
\text { Rate (ug/L/h) }\end{array}$ & \begin{tabular}{|c|}
$\begin{array}{c}\text { Minimum Rate } \\
(\mathrm{ug} / \mathrm{L} / \mathrm{h})\end{array}$ \\
\end{tabular} & $\begin{array}{c}\text { Maximum } \\
\text { Rate (ug/L/h) }\end{array}$ \\
\hline 25 & High & $1.80 \mathrm{E}+03$ & $4.05 \mathrm{E}+03$ & $2.09 \mathrm{E}+03$ & $2.93 \mathrm{E}+03$ & $1.29 \mathrm{E}+03$ & $1.68 \mathrm{E}+03$ & $9.41 \mathrm{E}+02$ & $1.87 \mathrm{E}+03$ \\
\hline 45 & High & $4.00 \mathrm{E}+03$ & $4.09 \mathrm{E}+03$ & $2.53 \mathrm{E}+03$ & $4.15 \mathrm{E}+03$ & $2.00 \mathrm{E}+03$ & $3.25 \mathrm{E}+03$ & $1.79 \mathrm{E}+03$ & $2.68 \mathrm{E}+03$ \\
\hline \multirow[t]{3}{*}{65} & High & $2.15 \mathrm{E}+03$ & $6.82 \mathrm{E}+03$ & $2.87 \mathrm{E}+03$ & $5.35 \mathrm{E}+03$ & $1.78 \mathrm{E}+03$ & $4.72 \mathrm{E}+03$ & $2.34 \mathrm{E}+03$ & $3.62 \mathrm{E}+03$ \\
\hline & & \multicolumn{4}{|c|}{ Strontium } & \multicolumn{4}{|c|}{ Plutonium } \\
\hline & & \multicolumn{2}{|c|}{ Mixed } & \multicolumn{2}{|c|}{ Unmixed } & \multicolumn{2}{|c|}{ Mixed } & \multicolumn{2}{|c|}{ Unmixed } \\
\hline $\begin{array}{c}\text { Temperature } \\
\left({ }^{\circ} \mathrm{C}\right) \\
\end{array}$ & $\begin{array}{l}\text { Solution } \\
\text { Activity }\end{array}$ & \begin{tabular}{|c|}
$\begin{array}{c}\text { Minimum Rate } \\
(\mathrm{ug} / \mathrm{L} / \mathrm{h})\end{array}$ \\
\end{tabular} & $\begin{array}{c}\text { Maximum } \\
\text { Rate }(\mathrm{ug} / \mathrm{L} / \mathrm{h})\end{array}$ & $\begin{array}{c}\text { Minimum Rate } \\
(\mathrm{ug} / \mathrm{L} / \mathrm{h})\end{array}$ & $\begin{array}{c}\text { Maximum } \\
\text { Rate }(\mathrm{ug} / \mathrm{L} / \mathrm{h})\end{array}$ & \begin{tabular}{|c|}
$\begin{array}{c}\text { Minimum Rate } \\
(\mathrm{ug} / \mathrm{L} / \mathrm{h})\end{array}$ \\
\end{tabular} & $\begin{array}{c}\text { Maximum } \\
\text { Rate }(\mathrm{ug} / \mathrm{L} / \mathrm{h})\end{array}$ & \begin{tabular}{|c|}
$\begin{array}{c}\text { Minimum Rate } \\
(\mathrm{ug} / \mathrm{L} / \mathrm{h})\end{array}$ \\
\end{tabular} & $\begin{array}{c}\text { Maximum } \\
\text { Rate (ug/L/h) }\end{array}$ \\
\hline 25 & Low & 2.42 & 2.96 & 2.37 & 3.38 & 1.83 & 2.72 & 2.01 & 3.17 \\
\hline 45 & Low & 2.69 & 2.70 & 2.23 & 2.28 & 0.133 & 0.275 & 0.201 & 0.214 \\
\hline 65 & Low & 2.84 & 2.87 & 3.10 & 3.12 & 0.133 & 0.275 & 0.314 & 0.346 \\
\hline
\end{tabular}

\begin{tabular}{|c|c|c|c|c|c|c|c|c|c|}
\hline \multirow[b]{3}{*}{$\begin{array}{c}\text { Temperature } \\
\left({ }^{\circ} \mathrm{C}\right) \\
\end{array}$} & \multirow[b]{3}{*}{$\begin{array}{l}\text { Solution } \\
\text { Activity }\end{array}$} & \multicolumn{4}{|c|}{ Neptunium } & \multicolumn{4}{|c|}{ Uranium } \\
\hline & & \multicolumn{2}{|c|}{ Mixed } & \multicolumn{2}{|c|}{ Unmixed } & \multicolumn{2}{|c|}{ Mixed } & \multicolumn{2}{|c|}{ Unmixed } \\
\hline & & $\begin{array}{c}\text { Minimum Rate } \\
(\mathrm{ug} / \mathrm{L} / \mathrm{h})\end{array}$ & $\begin{array}{c}\text { Maximum } \\
\text { Rate }(\mathrm{ug} / \mathrm{L} / \mathrm{h}) \\
\end{array}$ & $\begin{array}{c}\text { Minimum Rate } \\
(\mathrm{ug} / \mathrm{L} / \mathrm{h})\end{array}$ & $\begin{array}{c}\text { Maximum } \\
\text { Rate (ug/L/h) }\end{array}$ & $\begin{array}{c}\text { Minimum Rate } \\
(\mathrm{ug} / \mathrm{L} / \mathrm{h})\end{array}$ & $\begin{array}{c}\text { Maximum } \\
\text { Rate }(\mathrm{ug} / \mathrm{L} / \mathrm{h})\end{array}$ & $\begin{array}{c}\text { Minimum Rate } \\
(\mathrm{ug} / \mathrm{L} / \mathrm{h})\end{array}$ & $\begin{array}{c}\text { Maximum } \\
\text { Rate (ug/L/h) }\end{array}$ \\
\hline 25 & Low & $2.75 \mathrm{E}+02$ & $4.22 \mathrm{E}+02$ & $2.92 \mathrm{E}+02$ & $5.13 \mathrm{E}+02$ & $3.60 \mathrm{E}+02$ & $4.46 \mathrm{E}+02$ & $3.16 \mathrm{E}+02$ & $7.47 \mathrm{E}+02$ \\
\hline 45 & Low & $2.97 \mathrm{E}+02$ & $3.19 \mathrm{E}+02$ & $2.56 \mathrm{E}+02$ & $2.70 \mathrm{E}+02$ & $6.15 \mathrm{E}+02$ & $6.54 \mathrm{E}+02$ & $5.44 \mathrm{E}+02$ & $5.72 \mathrm{E}+02$ \\
\hline 65 & Low & $2.13 \mathrm{E}+02$ & $2.13 \mathrm{E}+02$ & $2.25 \mathrm{E}+02$ & $2.25 \mathrm{E}+02$ & $6.55 \mathrm{E}+02$ & $7.19 \mathrm{E}+02$ & $7.34 \mathrm{E}+02$ & $7.57 \mathrm{E}+02$ \\
\hline
\end{tabular}

Additional tests compared mixing in the orbital shaker and magnetic stirring using a $4.5 \mathrm{M} \mathrm{Na}$ salt solution and approximately $1.6 \mathrm{~g} / \mathrm{L}$ of MST. In the stirring tests, a Teflon ${ }^{\mathrm{TM}_{-}}$-coated magnetic stirring bar was inserted into the test bottle and rotated at $700 \mathrm{rpm}$ at ambient laboratory temperature $\left(17.6 \pm 0.26{ }^{\circ} \mathrm{C}\right)$. The 700 -rpm rotation speed was sufficient to suspend the MST solids throughout the test solution. Tests in the waterbath shaker $(200 \mathrm{rpm})$ were temperature controlled for the duration of the test at $20.78 \pm 0.19{ }^{\circ} \mathrm{C}$. The 200 -rpm orbital shaker speed agitated the solution, but did not suspend the majority of the MST solids. In these tests, sampling occurred at approximately $0.3,0.5,0.75,1.0,1.5,2.0,4.0,7.0$, and 24 hour contact times. Analysis of the solutions was limited to $\mathrm{Sr}, \mathrm{Pu}$ and $\mathrm{Np}$ in this test set.

Figures $9(\mathrm{Sr}$ and $\mathrm{Pu})$ and $10(\mathrm{~Np})$ provide plots of the sorbate concentrations versus contact time. Table 2 provides the removal rates for $\mathrm{Sr}, \mathrm{Pu}$ and $\mathrm{Np}$, respectively, calculated from the change in concentration from the start of the test to the first sampling event (ca. 0.35 hours) and the sixth sampling event (ca. 2.0 hours). The reported uncertainty in the rate is the sum of the uncertainties in the analytical measurements. Removal rates for the tests mixed by the orbital shaker are not significantly different than those mixed with the magnetic stirrer at either sampling event. This indicates that the much greater mixing energy provided by the magnetic stirrer and evidenced by 
the MST solids being suspended throughout the solution has no effect on the removal rates of $\mathrm{Sr}$, $\mathrm{Pu}$ and $\mathrm{Np}$ by the MST in these laboratory-scale experiments.

Comparison of the 2-hour removal rates in this test set with those reported in Table 1 indicate similar rates for both strontium and neptunium. The rate for $\mathrm{Pu}$ is considerably lower in this test set $(2.13 \mu \mathrm{g} / \mathrm{L} / \mathrm{h})$ compared to that measured with the $6.0 \mathrm{M}$ Na high-activity salt solution $(49.2-$ $113 \mu \mathrm{g} / \mathrm{L} / \mathrm{h})$. The lower rate reflects the much lower initial $\mathrm{Pu}$ concentration for the $4.5 \mathrm{M}$ high activity salt solution $(5.85 \mu \mathrm{g} / \mathrm{L})$ compared to the $6.0 \mathrm{M}$ high-activity salt solution $(223 \mu \mathrm{g} / \mathrm{L})$. The measured $\mathrm{Pu}$ removal rate in this test set, $2.13(0.23) \mu \mathrm{g} / \mathrm{L} / \mathrm{h}$, at a contact of 2.05 hours is within the range calculated $(1.83-2.72 \mu \mathrm{g} / \mathrm{L} / \mathrm{h})$ for the low-activity $6.0 \mathrm{M} \mathrm{Na}$ salt solution which contained a similar initial Pu concentration $(6.66 \mu \mathrm{g} / \mathrm{L} \mathrm{Pu})$. Note that the higher concentration of MST solids in the latter test set (ca. $1.6 \mathrm{~g} / \mathrm{L}$ MST vs. $1.1 \mathrm{~g} / \mathrm{L}$ ) does not appear to have a significant influence on the adsorption rates.

Table 2. Sorbate Removal Rates Upon Contact of 4.5 M Na Salt Solution with $1.6 \mathrm{~g} / \mathrm{L}$ MST with Mixing Energy Supplied by Orbital Shaker and Magnetic Stirrer at Contact Times of About 0.35 and 2.0 Hours

\begin{tabular}{ccccc} 
& \multicolumn{4}{c}{ Removal Rate $(\boldsymbol{\mu g} / \mathbf{L} / \mathbf{h})$} \\
Sorbate & \multicolumn{2}{c}{ Orbital Shaker } & \multicolumn{2}{c}{ Magnetic Stirrer } \\
& $\underline{\mathbf{0 . 3 8} \mathbf{~ h}}$ & $\underline{\mathbf{2 . 0 5} \mathbf{~ h}}$ & $\underline{\mathbf{0 . 3 0} \mathbf{~ h}}$ & $\underline{\mathbf{1 . 9 8 ~ h}}$ \\
$\mathrm{Sr}$ & $166(9.94)$ & $31.0(1.9)$ & $212(13)$ & $32.1(1.9)$ \\
$\mathrm{Pu}$ & $11.1(1.2)$ & $2.13(0.23)$ & $14.4(1.5)$ & $2.34(0.25)$ \\
$\mathrm{Np}$ & $7220(553)$ & $2030(156)$ & $7770(595)$ & $2020(155)$
\end{tabular}

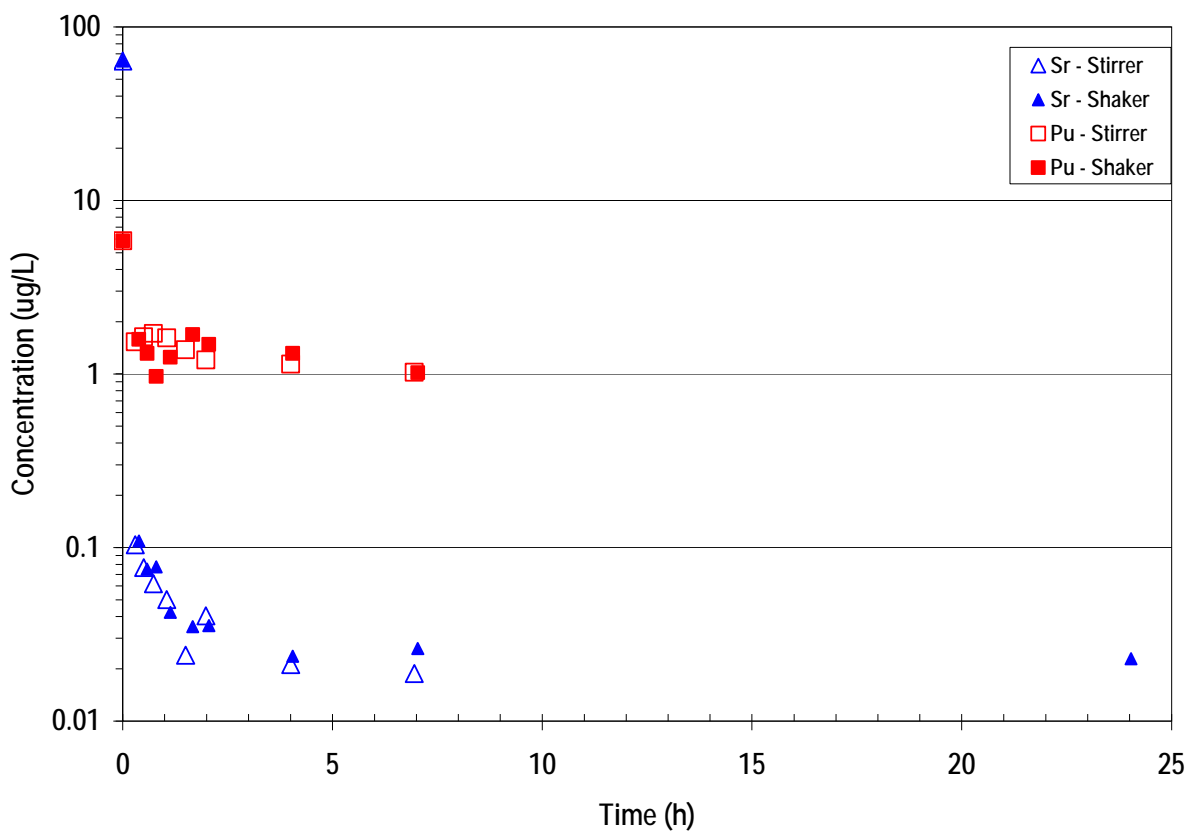

Figure 9. Comparison of Stirred and Agitated Mixing Conditions for the Removal of Strontium and Plutonium 


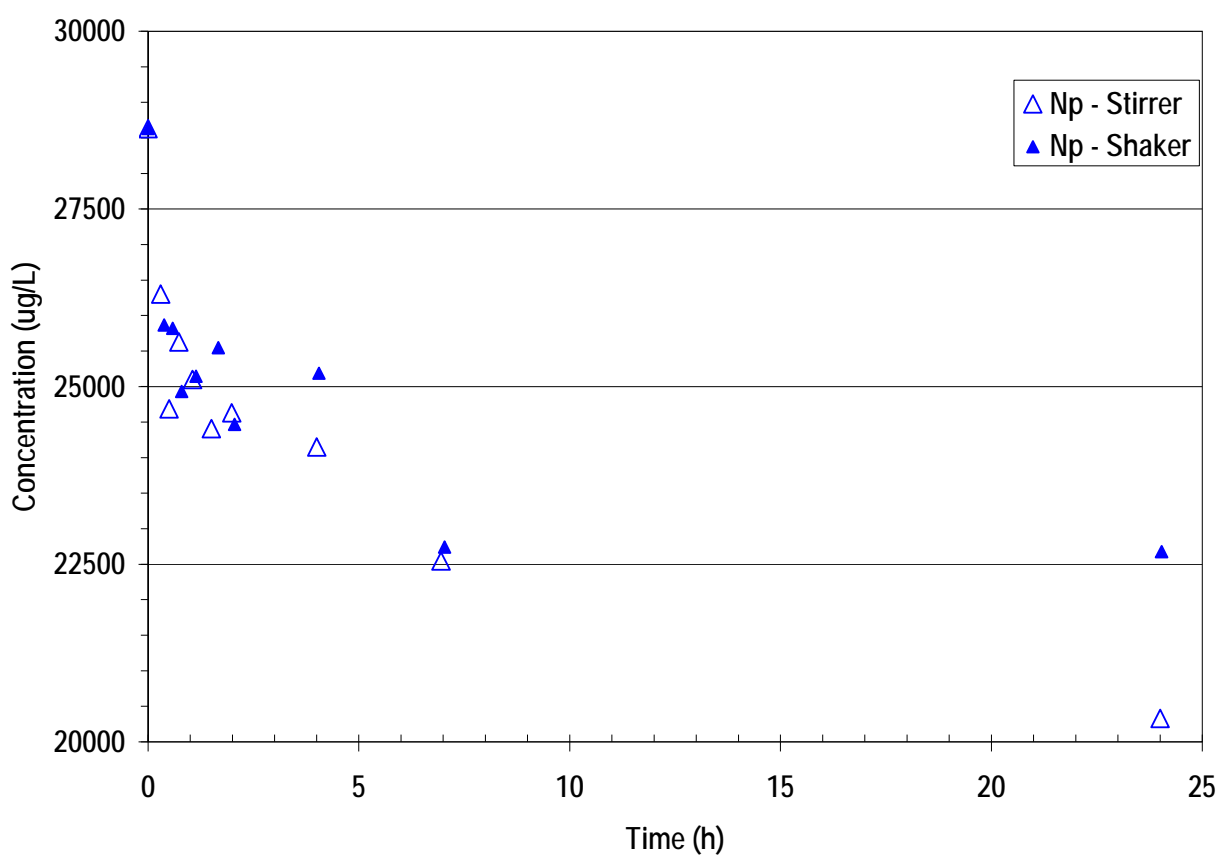

Figure 10. Comparison of Stirred and Agitated Mixing Conditions for the Removal of Neptunium

Researchers next measured the sorption rate upon the addition of either 0.2 or $0.4 \mathrm{~g} / \mathrm{L} \mathrm{MST}$ to a simulated waste solution $4.5 \mathrm{M}$ in Na concentration, $90.0 \mu \mathrm{g} / \mathrm{L} \mathrm{Sr}, 63.5 \mu \mathrm{g} / \mathrm{L} \mathrm{Pu}, 406 \mu \mathrm{g} / \mathrm{L} \mathrm{Np}$, and $9020 \mu \mathrm{g} / \mathrm{L} \mathrm{U}{ }^{2}$ These tests were conducted in the waterbath shaker at $25{ }^{\circ} \mathrm{C}$ at a shaking speed of $200 \mathrm{rpm}$ to provide data for sizing batch reactors for the various Salt Disposition Alternative flowsheets. These tests featured much more frequent sampling during the early contact times (target times included $0.25,0.50,0.75,1.0,1.5,2,4,8,24,72$ and 168 hours). Note that a MST concentration of $0.4 \mathrm{~g} / \mathrm{L}$ was subsequently selected as the baseline concentration for the use of MST in the Actinide Removal Process (ARP) and Salt Waste Processing Facility (SWPF).

Figures $11-14$ provide plots of the average sorbate concentration $(\mu \mathrm{g} / \mathrm{L})$ versus contact time $(\mathrm{h})$ at the two MST concentrations. Non-linear removal of $\mathrm{Sr}$ and $\mathrm{Pu}$ occurs after the first sampling event $(0.25 \mathrm{~h})$. For $\mathrm{Np}$ and $\mathrm{U}$, non-linear removal is evident after about 0.75 to 1.0 hours of contact. Table 4 provides the calculated removal rates $(\mu \mathrm{g} / \mathrm{L} / \mathrm{h})$ for each of the sorbates over a range of contact times up to about two hours. The observed rapid and non-linear change in sorbate concentrations is indicative of an ion-exchange process in which the kinetics are controlled either by film diffusion or particle diffusion.

Particle diffusion is not believed to be the rate limiting step for this application based on the low sorbate loading onto MST and findings from transmission electron microscopy (TEM). The planned concentration of MST in the pretreatment process is $0.4 \mathrm{~g} / \mathrm{L}$. At this concentration and typical concentrations for $\mathrm{Sr}, \mathrm{Pu}, \mathrm{Np}$, and $\mathrm{U}$ in the waste solutions, only a small fraction (ca. $1-5 \%$ ) of the available ion-exchange capacity is used for sorbate removal. Particle diffusion is important in ion-exchangers that are in the form of beads having sizes of more than 200 microns and the presence of binders that are not active ion-exchangers. MST is a fine particulate 
solid that is about $1-20$ microns in size and contains no binders. High resolution TEM revealed that MST exhibits an inner amorphous region surrounded by a fibrous exterior that is about $100-$ 500 nanometers in thickness. ${ }^{9}$ This outer fibrous region would be expected to have sufficient ionexchange sites given the low sorbate loading. TEM analysis of Sr-loaded MST particles revealed that the $\mathrm{Sr}$ is located only in the outer fibrous region. ${ }^{9}$ Thus, diffusion of the sorbates into the particle interior is not occurring to any significant degree. Assuming that the solution film does not extend into the fibrous region, particle diffusion distances would be limited to the thickness of the fibrous region $(100-500 \mathrm{~nm})$, which is $2-3$ orders of magnitude shorter than that in ionexchange beads. It is likely that the outer fibrous region is in contact with the solution film, such that sorbate transport to active ion-exchange sites occurs without particle diffusion.

The calculated removal rates for Sr compare reasonably well with those reported in Tables 1 and 2. For example, the 2-hour removal rate for $\mathrm{Sr}$ measured about $40 \mu \mathrm{g} / \mathrm{L} / \mathrm{h}$ in a $6.0 \mathrm{M} \mathrm{Na}$ salt solution containing $80 \mu \mathrm{g} / \mathrm{L} \mathrm{Sr}$ and contacted with $1.1 \mathrm{~g} / \mathrm{L} \mathrm{MST}$ (Table 1 ), $31.0 \mu \mathrm{g} / \mathrm{L} / \mathrm{h}$ for $4.5 \mathrm{M}$ Na salt solution containing $63.5 \mu \mathrm{g} / \mathrm{L} \mathrm{Sr}$ and contacted with $1.6 \mathrm{~g} / \mathrm{L} \mathrm{MST} \mathrm{(Table} \mathrm{2)} \mathrm{and} 44 \mu \mathrm{g} / \mathrm{L} / \mathrm{h}$ for a $4.5 \mathrm{M} \mathrm{Na}$ salt solution containing $90 \mu \mathrm{g} / \mathrm{L} \mathrm{Sr}$ and contacted with 0.2 or $0.4 \mathrm{~g} / \mathrm{L} \mathrm{MST}$ (Table 3). The good agreement reflects the relatively small change in initial $\mathrm{Sr}$ concentration (63.5 - 90 $\mu \mathrm{g} / \mathrm{L}$ ) across the 3 data sets. For $\mathrm{Pu}, \mathrm{Np}$ and $\mathrm{U}$, the comparison is poorer given the broader range of initial concentrations of the sorbates (e.g., $5.85-213 \mu \mathrm{g} / \mathrm{L}$ for $\mathrm{Pu}, 406-28,600 \mu \mathrm{g} / \mathrm{L}$ for $\mathrm{Np}$ and $9,020-20,800 \mu \mathrm{g} / \mathrm{L}$ for $\mathrm{U})$ and the variation in MST concentrations $(0.2-1.6 \mathrm{~g} / \mathrm{L})$.

Table 3. Calculated Sorbate Removal Rates from Contact of a 4.5 M Na Salt Solution with 0.2 or $0.4 \mathrm{~g} / \mathrm{L}$ MST

\begin{tabular}{|c|c|c|c|c|c|}
\hline $\begin{array}{c}{[\mathrm{MST}]} \\
\underline{(\mathrm{g} / \mathrm{L})}\end{array}$ & $\begin{array}{c}\text { Contact Time } \\
\text { (hours) }\end{array}$ & $\begin{array}{c}-\mathrm{d}[\mathrm{Sr}] / \mathrm{dt} \\
\underline{(\mu \mathrm{g} / \mathrm{L} / \mathrm{h})} \\
\end{array}$ & $\begin{array}{c}-\mathrm{d}[\mathrm{Pu}] / \mathrm{dt} \\
\underline{(\mu \mathrm{g} / \mathrm{L} / \mathrm{h})}\end{array}$ & $\begin{array}{r}-\mathrm{d}[\mathrm{Np}] / \mathrm{dt} \\
\underline{(\mu \mathrm{g} / \mathrm{L} / \mathrm{h})} \\
\end{array}$ & $\begin{array}{l}-\mathrm{d}[\mathrm{U}] / \mathrm{dt} \\
\underline{(\mu \mathrm{g} / \mathrm{L} / \mathrm{h})}\end{array}$ \\
\hline 0.2 & 0.29 & 301 & 144 & 136 & 302 \\
\hline 0.2 & 0.54 & 163 & 83.6 & 155 & 1270 \\
\hline 0.2 & 0.77 & 116 & 61.9 & 127 & 1180 \\
\hline 0.2 & 1.02 & 87.4 & 47.2 & 112 & 470 \\
\hline 0.2 & 2.03 & 43.8 & 24.9 & 64.7 & 465 \\
\hline 0.4 & 0.28 & 324 & 187 & 259 & 1930 \\
\hline 0.4 & 0.53 & 170 & 103 & 203 & 2230 \\
\hline 0.4 & 0.76 & 118 & 71.9 & 155 & 1860 \\
\hline 0.4 & 1.01 & 88.8 & 54.4 & 149 & 1210 \\
\hline 0.4 & 2.03 & 44.1 & 27.9 & 83.1 & 679 \\
\hline
\end{tabular}




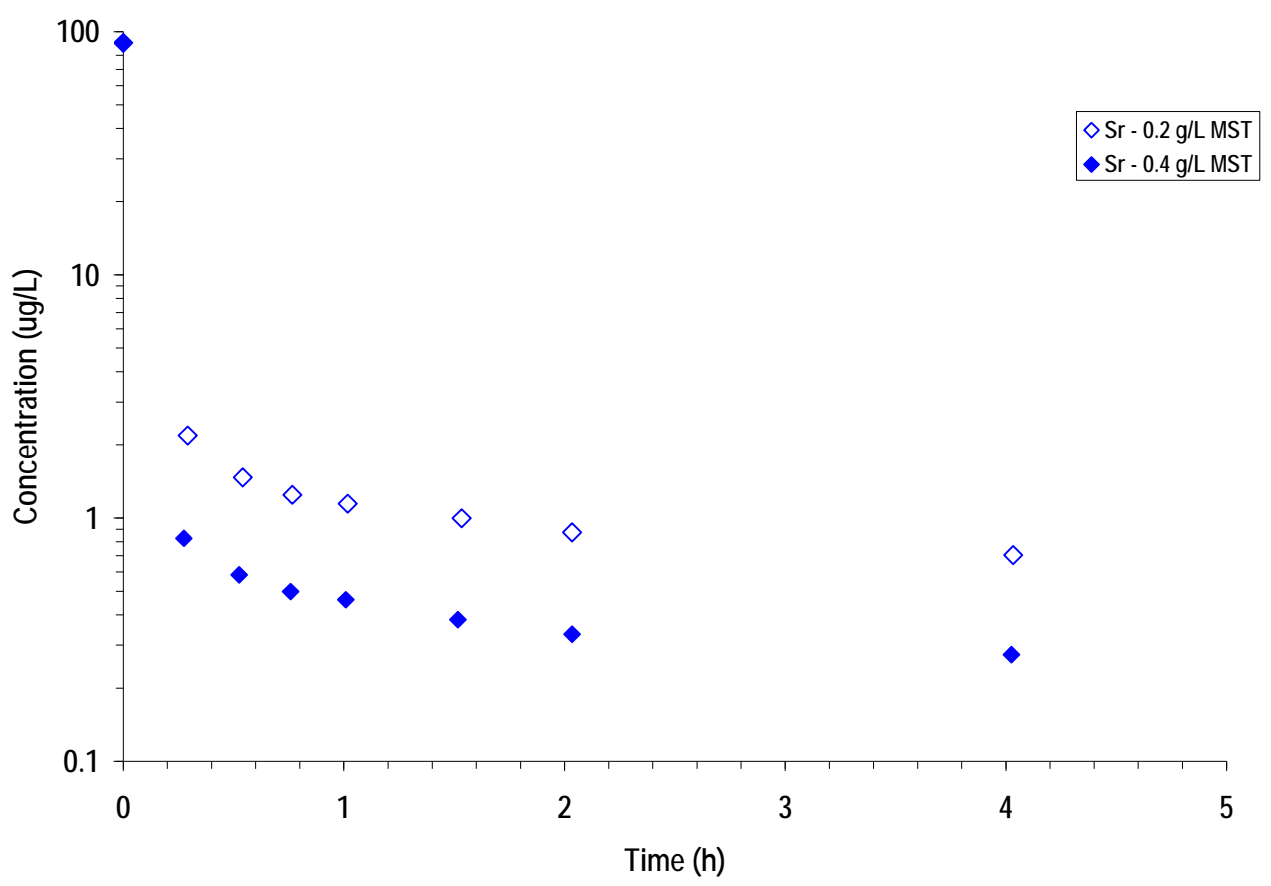

Figure 11. Strontium Concentration versus Time upon Contact of a $4.5 \mathrm{M}$ Na Salt Solution Containing $90 \mu \mathrm{g} / \mathrm{L} \mathrm{Sr}$ with 0.2 or $0.4 \mathrm{~g} / \mathrm{L}$ MST at $25^{\circ} \mathrm{C}$ with Mixing Provided by Orbital Shaker at $200 \mathrm{rpm}$.

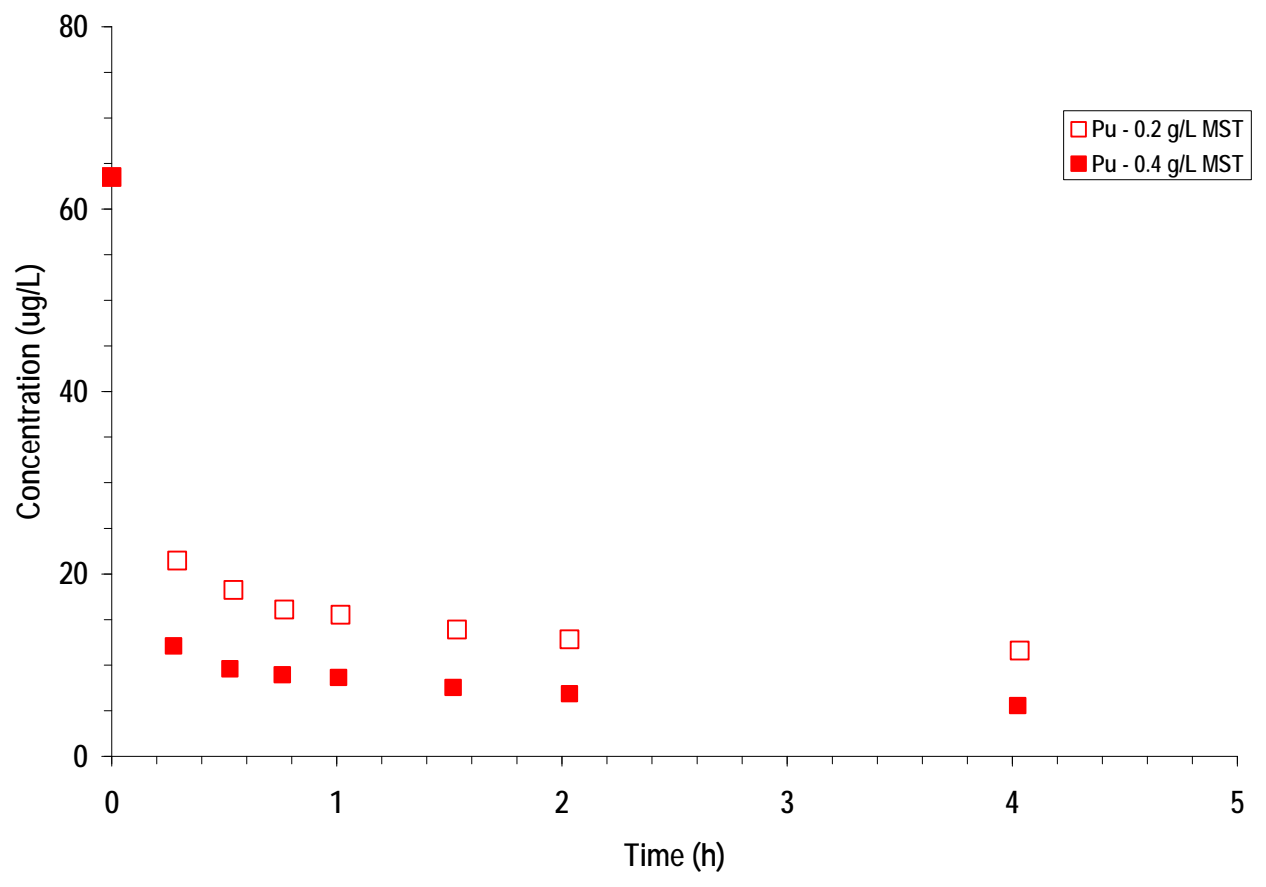

Figure 12. Plutonium Concentration versus Time upon Contact of a $4.5 \mathrm{M}$ Na Salt Solution Containing $63.5 \mu \mathrm{g} / \mathrm{L}$ Pu with 0.2 or $0.4 \mathrm{~g} / \mathrm{L}$ MST at $25^{\circ} \mathrm{C}$ with Mixing Provided by Orbital Shaker at $200 \mathrm{rpm}$. 


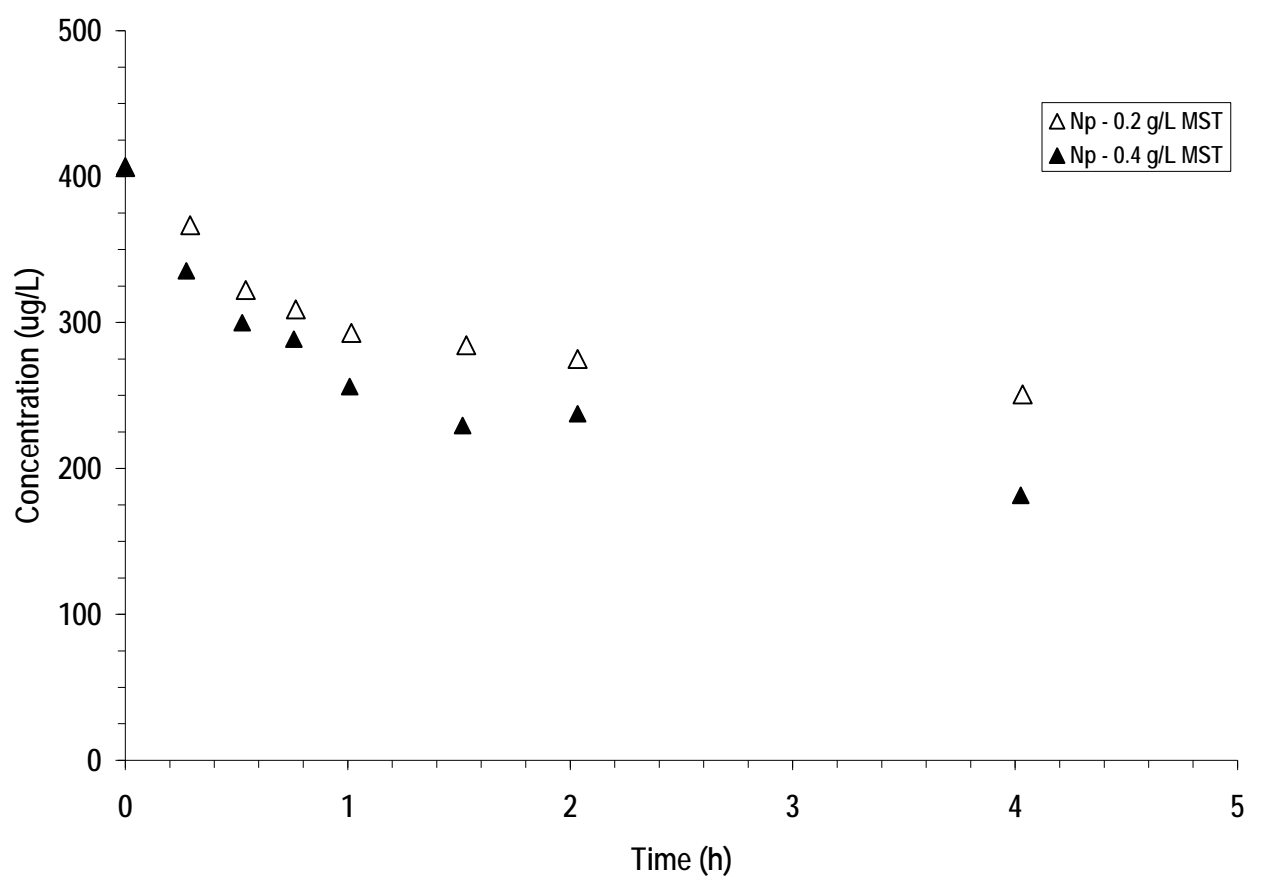

Figure 13. Neptunium Concentration versus Time upon Contact of a $4.5 \mathrm{M}$ Na Salt Solution Containing $406 \mu \mathrm{g} / \mathrm{L} \mathrm{Np}$ with 0.2 or $0.4 \mathrm{~g} / \mathrm{L} \mathrm{MST}$ at $25^{\circ} \mathrm{C}$ with Mixing Provided by Orbital Shaker at $200 \mathrm{rpm}$.

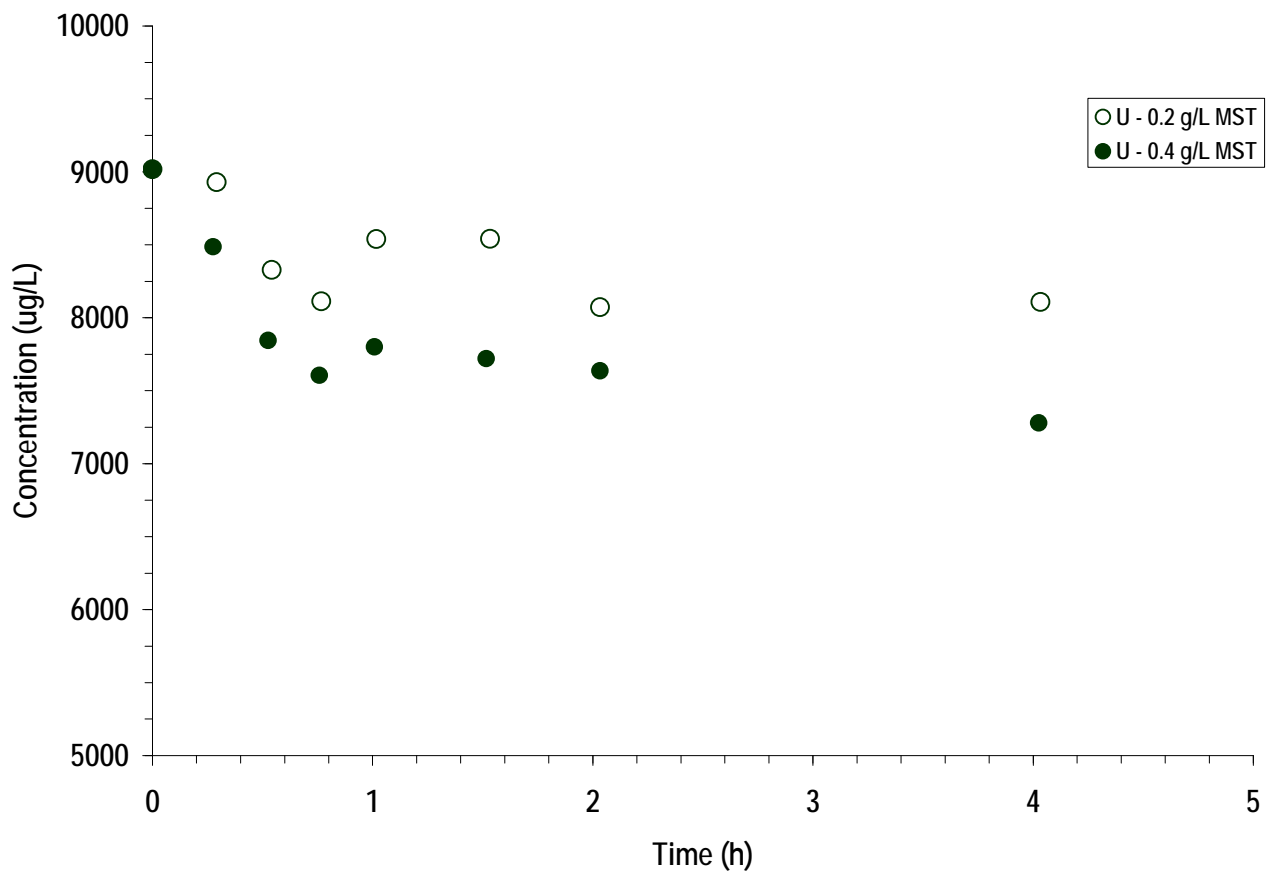

Figure 14. Uranium Concentration versus Time upon Contact of a 4.5 M Na Salt Solution Containing 9,020 $\mu \mathrm{g} / \mathrm{L} \mathrm{U}$ with 0.2 or $0.4 \mathrm{~g} / \mathrm{L}$ MST at $25^{\circ} \mathrm{C}$ with Mixing Provided by Orbital Shaker at 200 rpm. 
The next test set featured treatment of actual tank waste solution with $0.2 \mathrm{~g} / \mathrm{L} \mathrm{MST}$ at $25{ }^{\circ} \mathrm{C}$. $^{3}$ Prior to the MST tests, the radioactive waste was first treated with sodium tetraphenylborate to reduce the gamma activity due to ${ }^{137} \mathrm{Cs}$ allowing the testing to occur in a radiohood. The treated waste solution was evaporated to increase the sodium concentration to $7.5 \mathrm{M}$. Researchers added ${ }^{85} \mathrm{Sr}$ as a radiotracer and ${ }^{237} \mathrm{~Np}$ to increase the $\mathrm{Np}$ concentration to allow detection in the MST tests. A portion of the waste was diluted with water to provide a solution with a sodium concentration of $4.5 \mathrm{M}$. The resulting 7.5 and $4.5 \mathrm{M} \mathrm{Na}$ solutions were filtered to remove any undissolved solids. The adsorption tests consisted of placing $120 \mathrm{~mL}$ of the solutions into plastic bottles, adding MST to achieve a concentration of $0.2 \mathrm{~g} / \mathrm{L}$, and agitating in a waterbath shaker at $200 \mathrm{rpm}$ and $25^{\circ} \mathrm{C}$. Samples were taken after $0.25,0.5,0.75,1,1.5,2,4,8,24,96$, and 168 hours of contact.

Figures $15-17$ provide plots of the $\mathrm{Sr}, \mathrm{Pu}$ and $\mathrm{Np}$ concentrations, respectively, versus contact time. As shown in the figures, changes in the $\mathrm{Sr}, \mathrm{Pu}$ and $\mathrm{Np}$ concentration with time proved similar for the actual tank waste solutions to that in the earlier tests with simulated waste solutions. Similar findings were observed with $\mathrm{U}$ (plot not shown). Note that the removal of $\mathrm{Pu}$ in the tank waste and simulated $7.5 \mathrm{M} \mathrm{Na}$ solutions initially containing lower plutonium concentrations (ca. $10-13 \mu \mathrm{g} / \mathrm{L}$ ) proved low compared to that with the simulated waste solution at much higher initial $\mathrm{Pu}$ concentration $(280 \mu \mathrm{g} / \mathrm{L})$

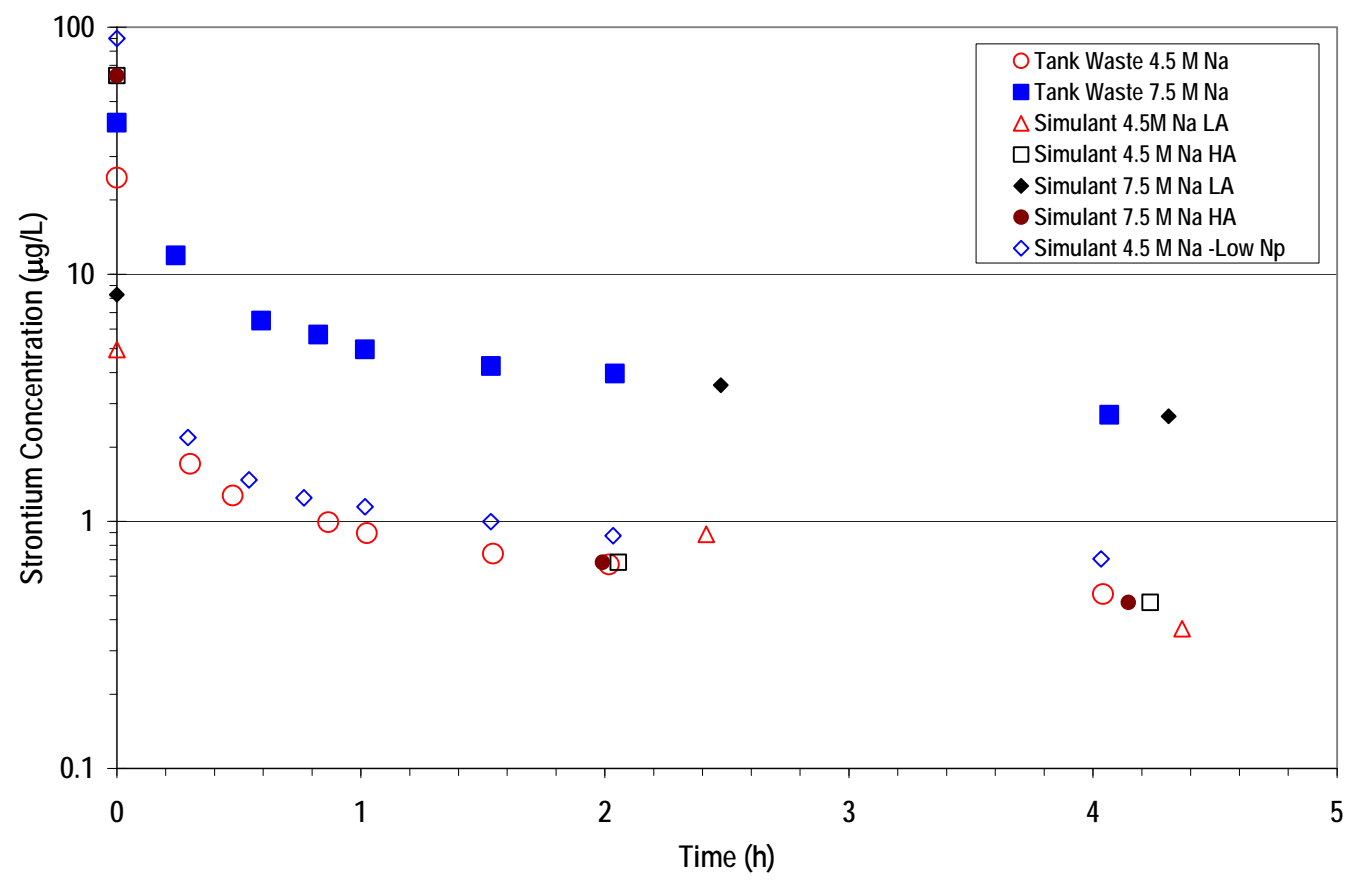

Figure 15. Comparison of Strontium Removal by MST in Actual and Simulated Tank Waste Solution 
SRNL-STI-2010-00438

Rev. 0

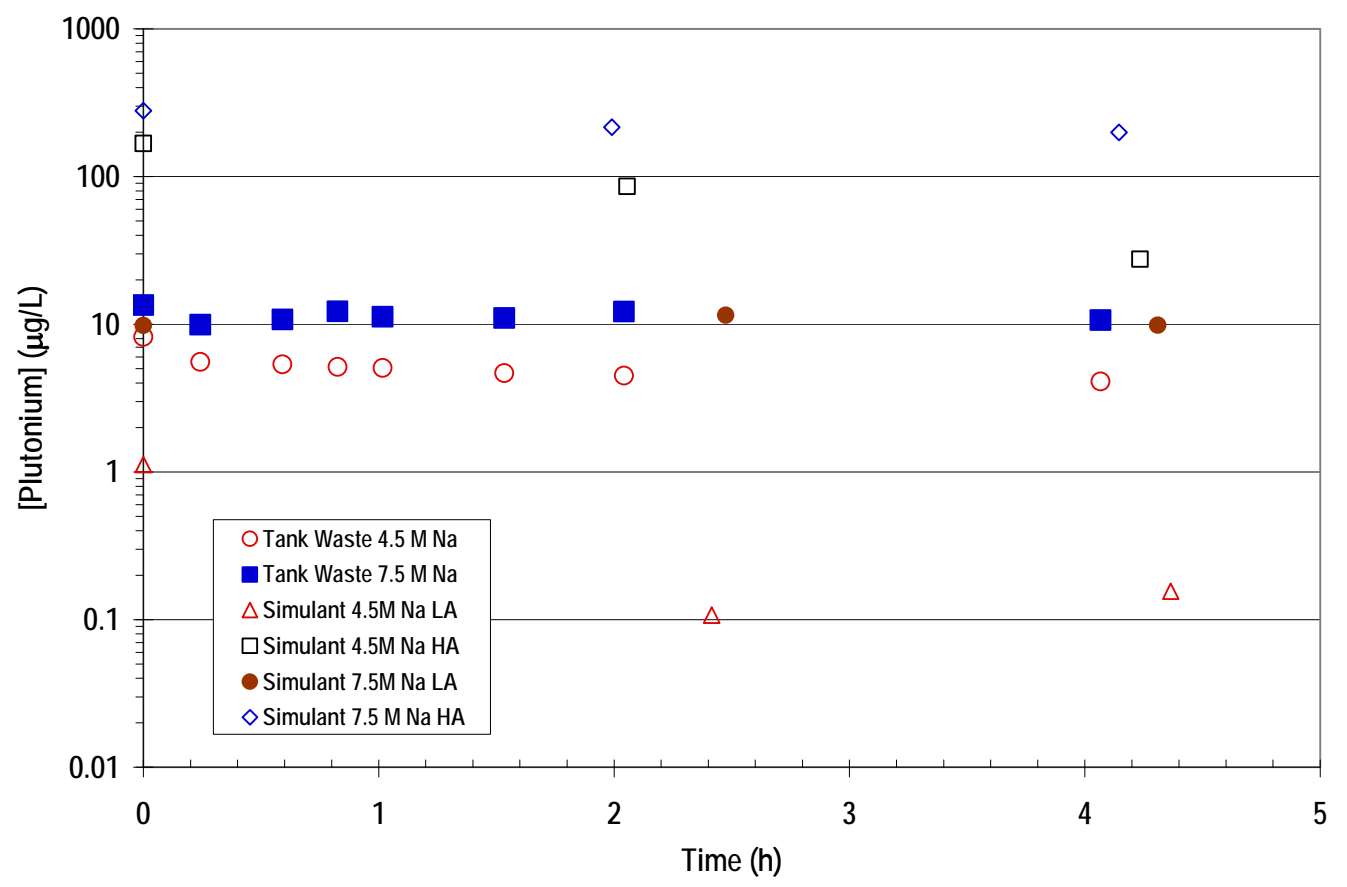

Figure 16. Comparison of Plutonium Removal by MST in Actual and Simulated Tank Waste Solutions

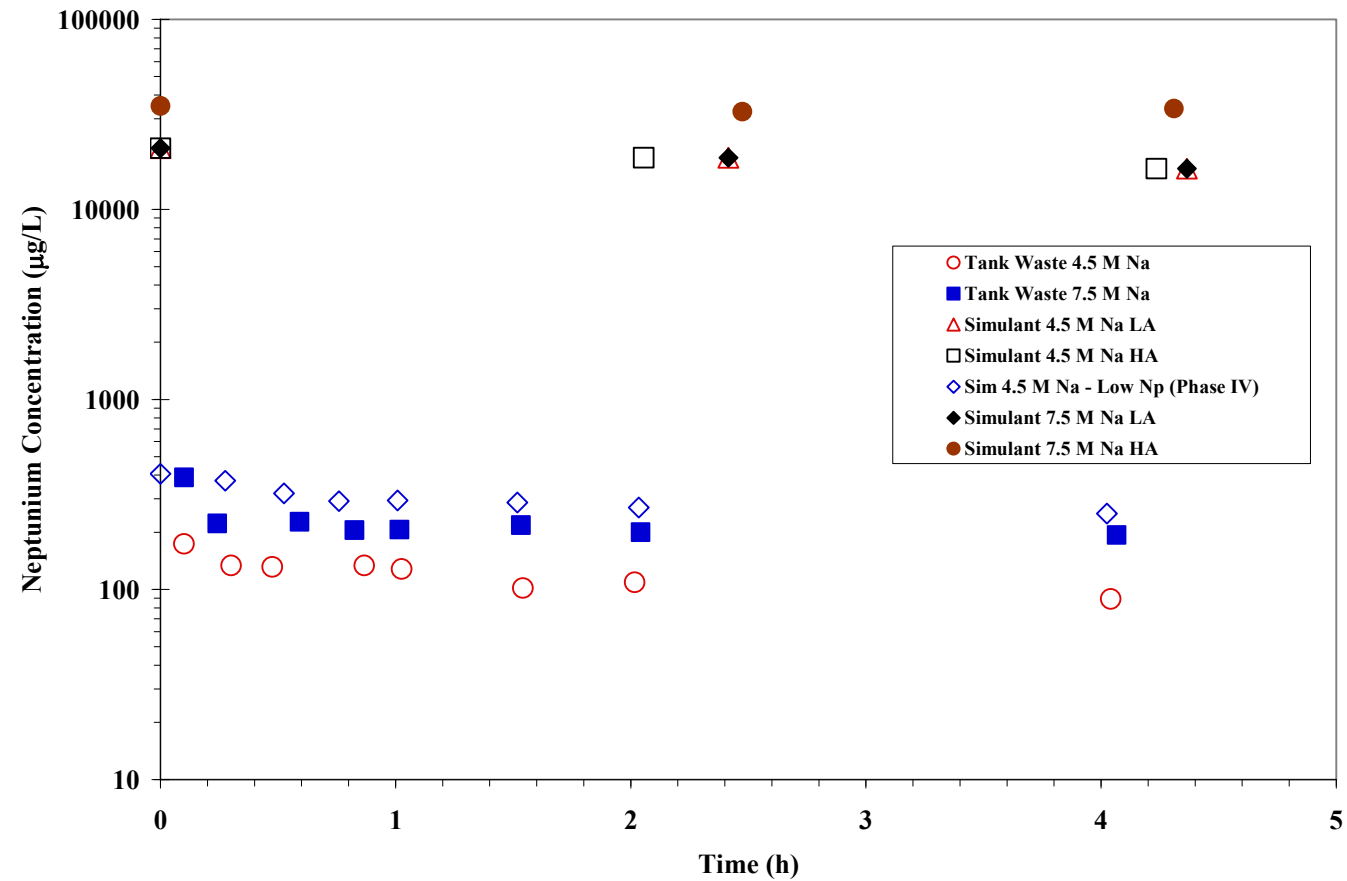

Figure 17. Comparison of Neptunium Removal by MST in Actual and Simulated Tank Waste Solutions 
Following the tests with actual tank waste, researchers tested a simulated waste having a $5.6 \mathrm{M}$ sodium concentration and higher plutonium concentration. ${ }^{4}$ The $5.6 \mathrm{M}$ sodium concentration had been selected as the baseline concentration for salt processing. The higher plutonium concentration reflected system planning forecasts that indicated higher plutonium concentrations may be present in the salt waste solutions. These tests used the same experimental protocol as the earlier simulant tests at a temperature of $25^{\circ} \mathrm{C}$ and with MST additions at 0.2 and $0.4 \mathrm{~g} / \mathrm{L}$.

Plots of sorbate concentrations versus time exhibited similar changes to those observed with the earlier test sets. Figure 18 provides a plot of the strontium decontamination factor (DF) versus contact time (h) for this test set $(5.6 \mathrm{M})$ as well as the previously tested $4.5 \mathrm{M}$ Na simulated waste solution and the actual tank wastes having $4.5 \mathrm{M}$ and $7.5 \mathrm{M}$ Na concentrations. Figure 19 shows a similar plot for the plutonium.

For each dataset, the Sr DF value increases very rapidly during the first $6-8$ hours of contact and then slows dramatically and appears to reach steady-state after 24 hours of contact. The extent of strontium uptake in the $5.6 \mathrm{M} \mathrm{Na}$ salt solution falls between that measured in both the $4.5 \mathrm{M} \mathrm{Na}$ actual tank waste and simulated waste solutions and the $7.5 \mathrm{M} \mathrm{Na}$ actual tank waste solution. This is the expected trend and reflects the influence of the ionic strength of the solution and the initial sorbate concentrations.

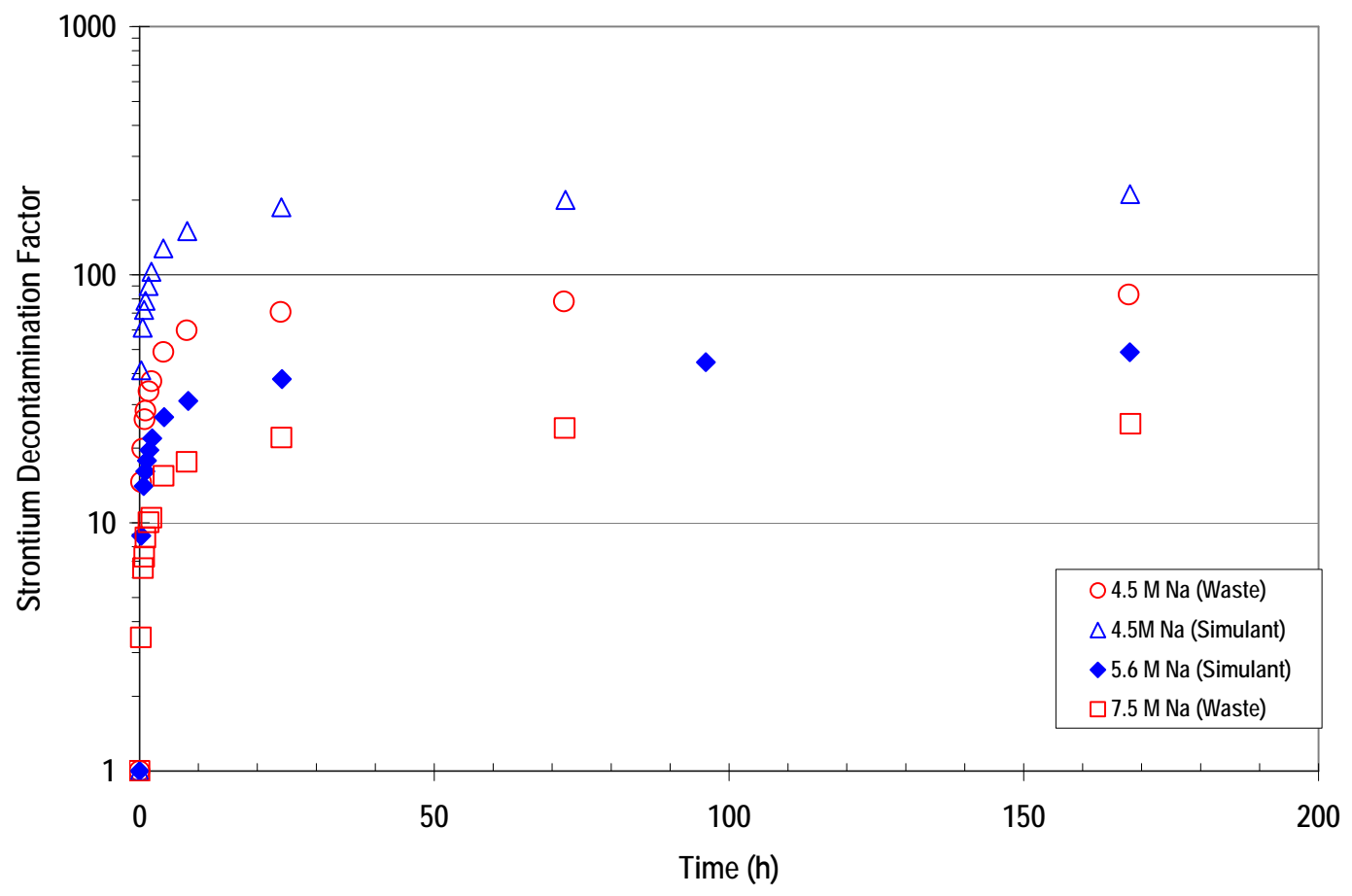

Figure 18. Strontium Decontamination Factor versus Time in Simulated and Actual Tank Waste Solutions at Various Sodium Concentrations upon Contact with 0.2 g/L MST 


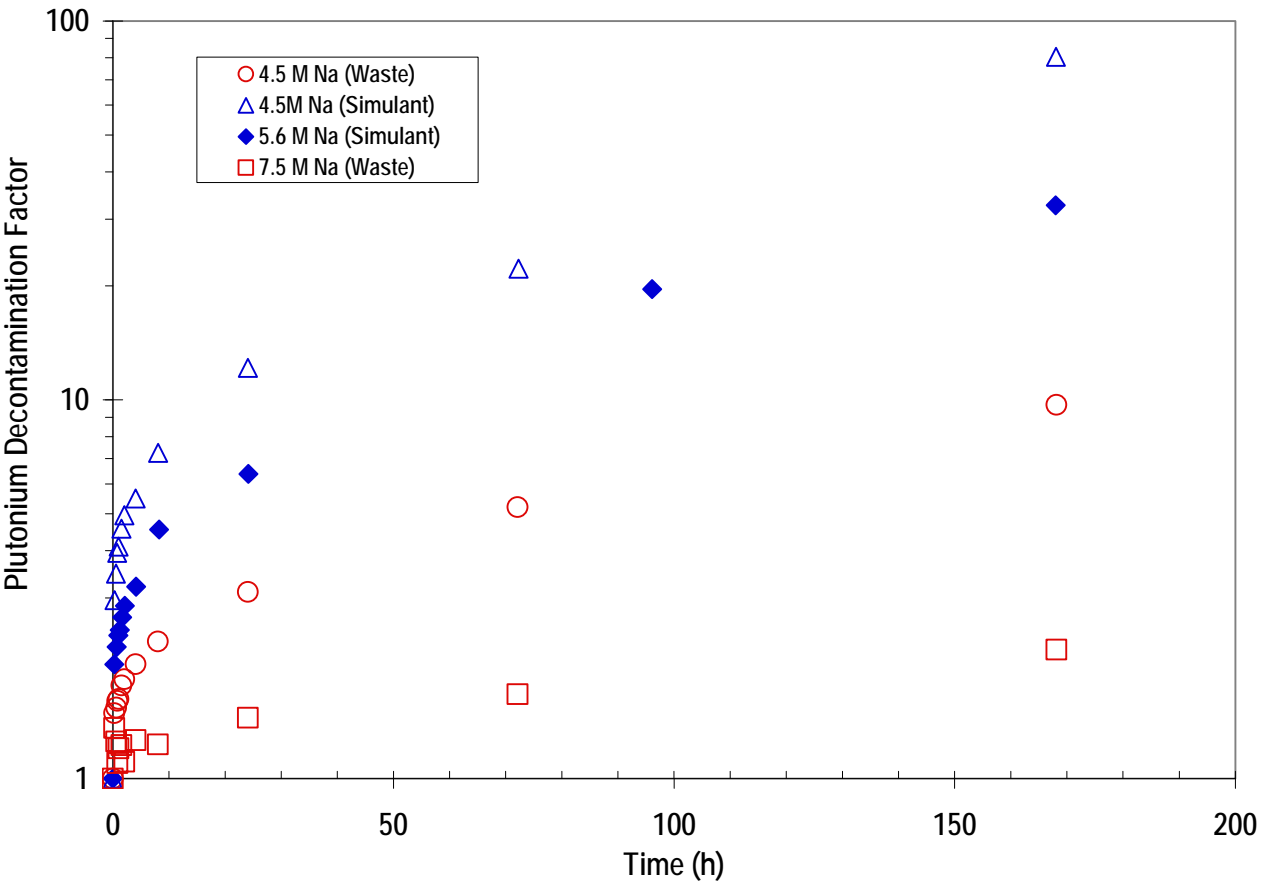

Figure 19. Plutonium Decontamination Factor versus Time in Simulated and Actual Tank Waste Solutions at Various Sodium Concentrations upon Contact with 0.2 g/L MST

Like strontium, Pu DF values increase very rapidly during the first $6-8$ hours of contact and then slows dramatically. Unlike strontium, Pu DF values slowly continue to slowly increase over the entire test period (168 hours) indicating that steady-state conditions for Pu removal have not been obtained when the test is concluded after 168 hours of contact. The Pu DF values for the $5.6 \mathrm{M}$ $\mathrm{Na}$ simulated waste solution are slightly smaller than those of the $4.5 \mathrm{M} \mathrm{Na}$ simulated waste solution, but higher than those measured for the $4.5 \mathrm{M} \mathrm{Na}$ tank waste solution. The relatively low $\mathrm{DF}$ value for $\mathrm{Pu}$ in the tank waste solution likely reflects the relatively low $\mathrm{Pu}$ concentration in this test set.

Four larger bench-scale tests of MST performance with actual tank waste solutions have been carried out. ${ }^{5}$ These tests represent factors of approximately $300-700$ scale increase compared to previous laboratory studies. The first three tests used a 100-L stainless steel reactor equipped with an air-driven agitator to mix MST with tank waste solutions. The speed of the agitator was not measured, but produced a visible vortex and, consequently, suspended the MST solids throughout the reactor vessel. The first two tests in this reactor each treated 66 liters of waste with enough MST to achieve a concentration of $0.52 \mathrm{~g} / \mathrm{L}$. The MST used in this test was produced by Optima Chemicals Group, LLC and identified as Lot \# MST-96-QAB-281. The waste solution was a combination of solution samples taken from Tanks $37 \mathrm{H}$ and $44 \mathrm{~F}$ diluted to a 5.6 $\mathrm{M} \mathrm{Na}$ concentration.

Figure 20 provides a plot of the ${ }^{90} \mathrm{Sr}$ activity versus time in the tests with the Tank $37 \mathrm{H} / 44 \mathrm{~F}$ combined waste solution. The data points identified as "Walker" represent those measured during the testing. The data points identified as "Peters" represent analysis of archived samples at a much later date. Sampling events during this test included 1, 2, 3, 8, 12, 24, and 30 hours. The ${ }^{90} \mathrm{Sr}$ activity decreased from $28.4 \mathrm{nCi} / \mathrm{g}$ to $5.53 \mathrm{nCi} / \mathrm{g}$ after one hour of contact with the MST. 
The 2-hour sample exhibited a high ${ }^{90} \mathrm{Sr}$ activity $(20.3 \mathrm{nCi} / \mathrm{g})$, but the remaining samples returned to around $5 \mathrm{nCi} / \mathrm{g}$. Thus, SRNL researchers suspect that the 2-hour sample result is high due to experimental errors or cross contamination from handling in the Shielded Cells. The analytical results for plutonium showed a small DF of 2.8 after 24 hours of contact (see Figure 21).

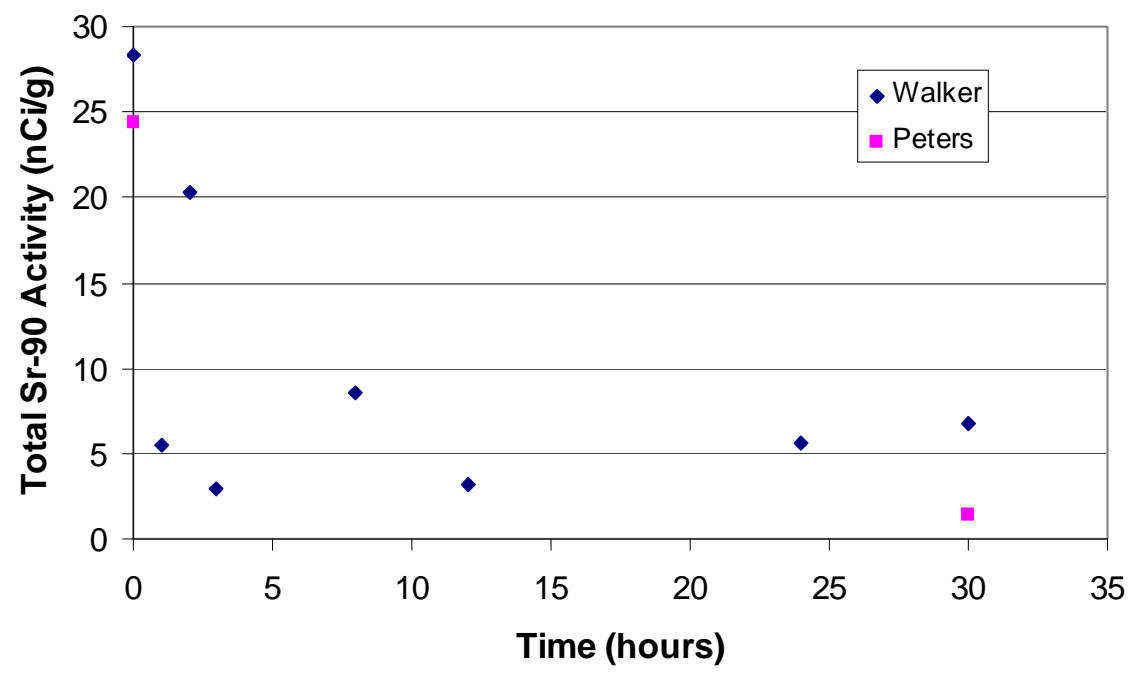

Figure 20. ${ }^{90} \mathrm{Sr}$ Activity versus Time in Tank 37H/44F Waste Solution upon Contact with $0.52 \mathrm{~g} / \mathrm{L}$ MST. Data points identified as "Walker" represent those measured during the testing. The data points identified as "Peters" represent analysis of archived samples at a later date.

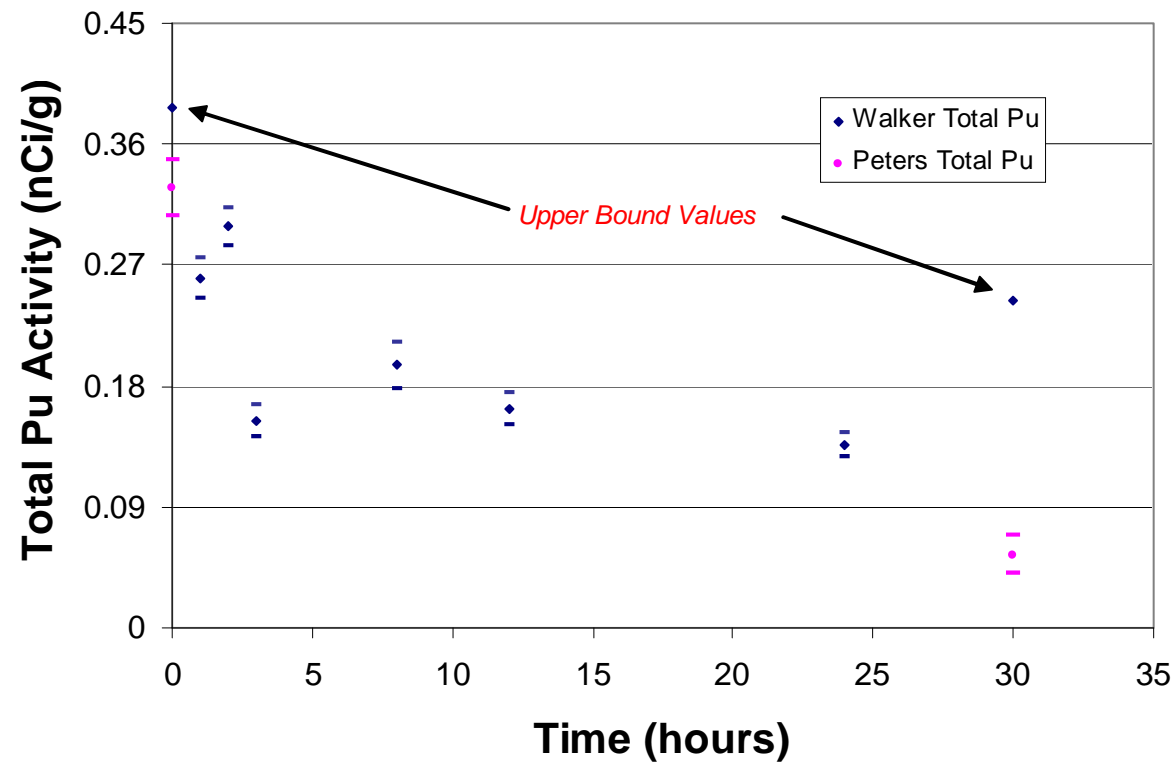

Figure 21. Plutonium Activity versus Time in Tank 37H/44F Waste Solution upon Contact with $0.52 \mathrm{~g} / \mathrm{L}$ MST. Data points identified as "Walker" represent those measured during the testing. The data points identified as "Peters" represent analysis of archived samples at a later date. 
A third test was also carried out in this reactor using $70 \mathrm{~L}$ of Tank $37 \mathrm{H}$ salt solution diluted to a 5.6 M Na concentration. A set of four, $90^{\circ}$-spaced 1.5-in wide baffles were installed in the reactor, each spaced 0.25 in from the wall and 0.5 in from the bottom of the reactor. The speed of the agitator was not measured, but the stirring was sufficient to generate a 1-3 inch vortex on the surface of the stirred solution. This mixing energy was likely sufficient to suspend all of the MST solids throughout the reactor vessel. The MST concentration in this test was $0.4 \mathrm{~g} / \mathrm{L}$. Figure 22 provides a plot of the ${ }^{90} \mathrm{Sr}$ activity versus time.

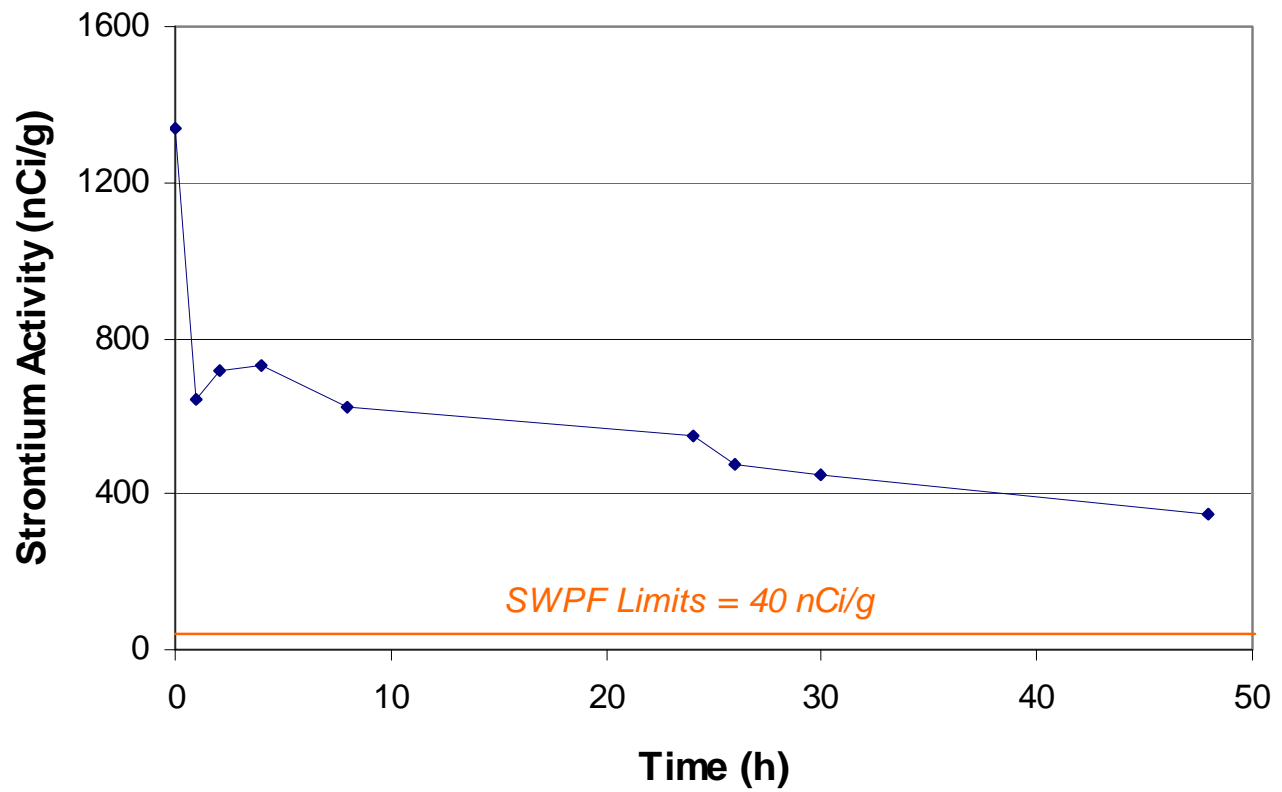

\section{Figure 22. ${ }^{90} \mathrm{Sr}$ Activity versus Time in Tank $37 \mathrm{H}$ Waste Solution upon Contact with $0.40 \mathrm{~g} / \mathrm{L} \mathrm{MST}$}

The final bench-scale testing at a larger scale used a stainless steel vessel having a 30-L working volume. The reactor design and mixing conditions in the tank were designed to provide the same hydraulic conditions as those in the nominal 5000-gallon strike tank used in the Actinide Removal Process. Based on engineering calculations, the mixing energy in this test was sufficient to lift the MST particles into the liquid phase. This test used archived Tank 37H/44F waste solution that had previously been contacted with MST and sent through the Caustic Side Solvent Extraction (CSSX) process to remove cesium. Stable strontium and cesium as well as ${ }^{85} \mathrm{Sr}$, depleted uranium, neptunium and plutonium, were added to the waste solution and the spiked waste allowed to equilibrate for three weeks prior to the MST performance test. The MST performance test added $0.4 \mathrm{~g} / \mathrm{L}$ MST (batch TNX) to the waste while stirring in the hydraulicallyscaled reactor. The experiment was sampled at 2, 4, 12, 18, 24, and 30 hours after the addition of the MST. A comparison test was also conducted in which $100 \mathrm{~mL}$ of the spiked-waste was contacted with $0.4 \mathrm{~g} / \mathrm{L}$ MST in polyethylene bottles agitated at $200 \mathrm{rpm}$ in a waterbath shaker as previously described. This test was sampled only after 24-hours of contact. 
Figures 23 and 24 provide plots of the ${ }^{85} \mathrm{Sr}$ and total $\mathrm{Pu}$ activity versus contact time, respectively. Included on the graphs, are the initial and 24-hour activities measured in the test using the waterbath shaker, which are labeled as "Hobbs". Rapid decreases in the ${ }^{85} \mathrm{Sr}$ and total $\mathrm{Pu}$ activities were observed in the experiment in the 30-L hydraulically-scaled reactor. Analysis of the 24-hour samples taken from the 30-L hydraulically-scaled reactor and the 0.10-L waterbath shaker experiments indicated very similar activities for ${ }^{85} \mathrm{Sr}$ (Fig. 23) and total Pu (Fig. 24) as well as that for neptunium and uranium (plots not shown). These findings suggested that the mixing intensity in the strike tank for the ARP facility is sufficient such that bulk transport of sorbates to the surface of the MST particles is not limiting the adsorption of strontium and actinides.

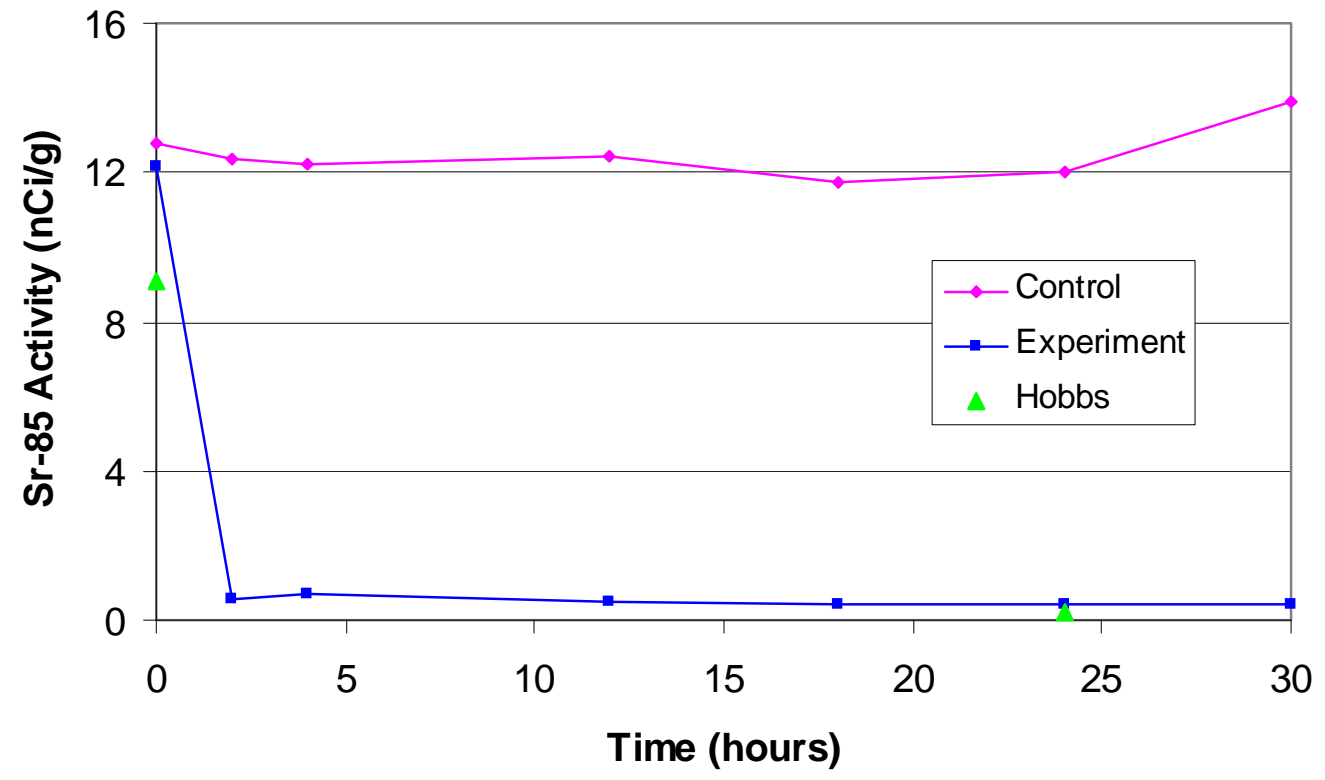

Figure 23. ${ }^{85} \mathrm{Sr}$ Activity versus Time for the Spiked Tank 37H/44F Waste Solution at upon Contact with $0.40 \mathrm{~g} / \mathrm{L} \mathrm{MST}$ 


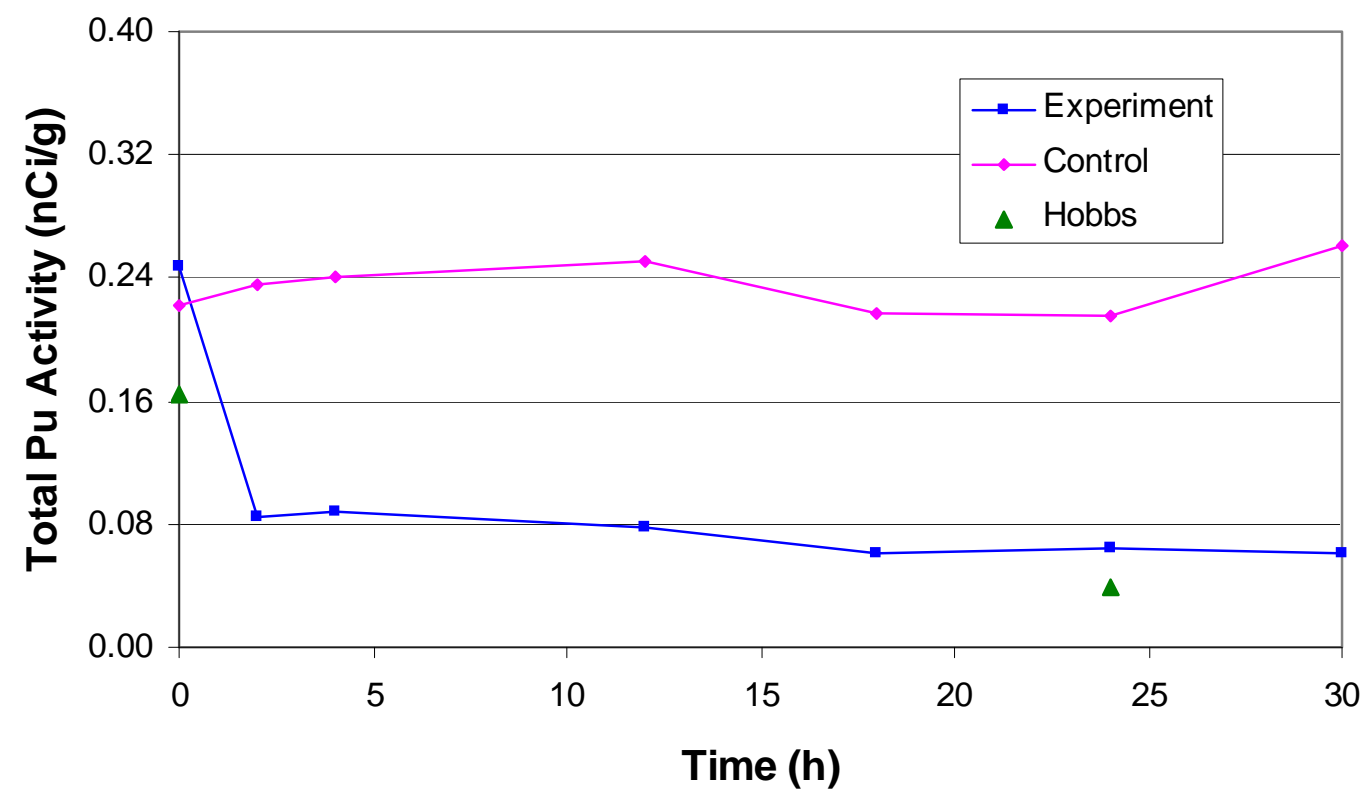

Figure 24. Pu Activity versus Time for the Spiked Tank 37H/44F Waste Solution at upon Contact with $0.40 \mathrm{~g} / \mathrm{L} \mathrm{MST}$

Thermodynamic and Kinetic Modeling

Fondeur et. al evaluated published isotherm models for the adsorption of $\mathrm{Sr}, \mathrm{Pu}, \mathrm{Np}$, and $\mathrm{U}$ onto MST using experimental data collected from numerous tests at SRNL. ${ }^{6}$ Of the 29 isotherm models investigated, the Dubinin-Astashov (DA) model provided good predictions for the adsorption of $\mathrm{Sr}$ and actinides with the fewest number of parameters and operations. Subsequently, Fondeur et. al updated the DA isotherm with additional experimental data and modified the form of the prediction models with a kinetic function. ${ }^{7,8}$ A number of kinetic functions were evaluated, including first order and second order models. However, the function derived by Rahn provided the best fit of the kinetic data from the simulant and tank waste testing. In this function, both film diffusion and intra-particle (or pore) diffusion control the rate of sorbate uptake.

Equation 1 provides the general form of the Rahn kinetic function,

$$
q_{S}(t)=q_{S-e q} x\left\lfloor 1-e^{-k t^{n}}\right\rfloor
$$

where $q_{S}(t)$ is the amount of a sorbate, $\mathrm{S}$, loaded onto MST at a time, $\mathrm{t}$, in units of $\mu \mathrm{mole} / \mathrm{g}$ of MST. The term $q_{S-e q}$ is the amount of a sorbate, S, loaded onto MST at equilibrium. The terms $k$ and $n$ are parameters derived from the experimental data.

Figures $25-28$ provide plots of the predicted and measured loading of $\mathrm{Sr}, \mathrm{Pu}, \mathrm{Np}$, and $\mathrm{U}$ onto MST versus time upon contact with $0.2 \mathrm{~g} / \mathrm{L}$ MST in a $6.0 \mathrm{M} \mathrm{Na}$ salt solution. The initial concentrations of each of the sorbates is that provided in Appendix A identified as Test Set \#1 [ref. 1] at $25^{\circ} \mathrm{C}$. Strontium removal is very fast and reaches equilibrium much more quickly than any of the actinides. Plutonium removal is also fast, but slower than Sr. Neptunium and uranium removal are slower than plutonium and under certain conditions continue for much longer than 1 
week at very high initial sorbate concentrations. Fairly good agreement has been observed between the predicted and measured sorbate concentrations in the laboratory-scale test data.

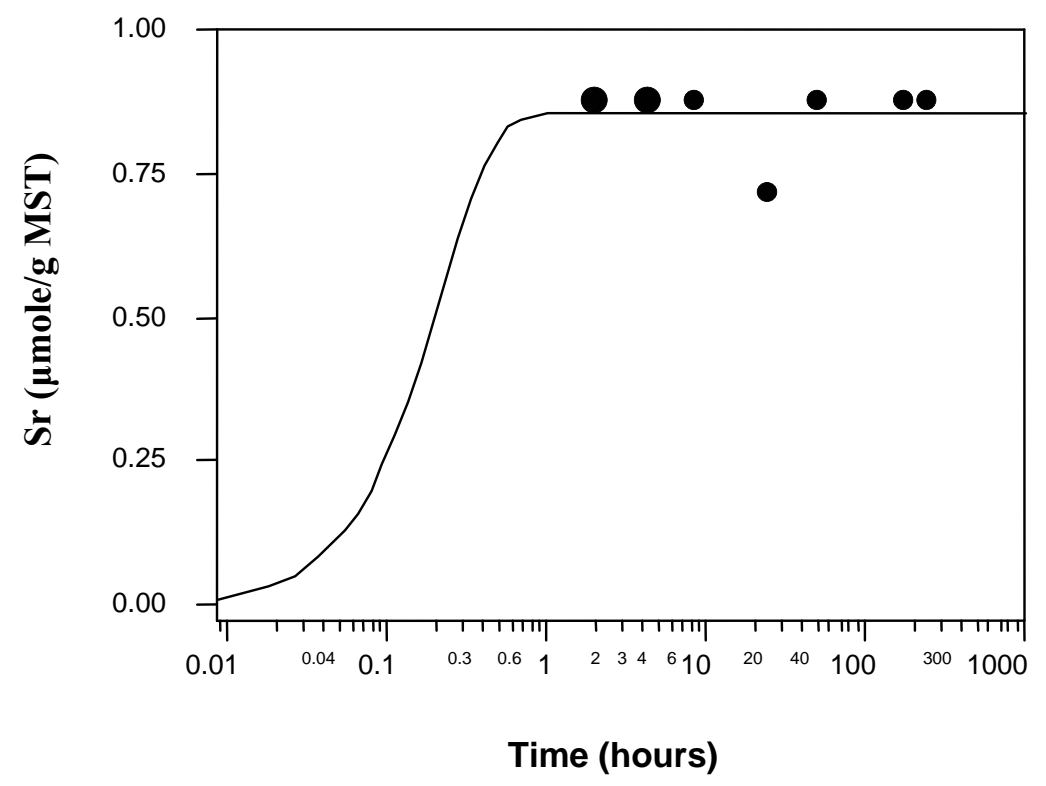

Figure 25. Sr loading on MST at $[\mathrm{Na}]=6 \mathrm{M}, \mathrm{T}=25^{\circ} \mathrm{C}$ and $0.2 \mathrm{~g} / \mathrm{L} \mathrm{MST}$. Filled circles are measured values. Line is predicted values.

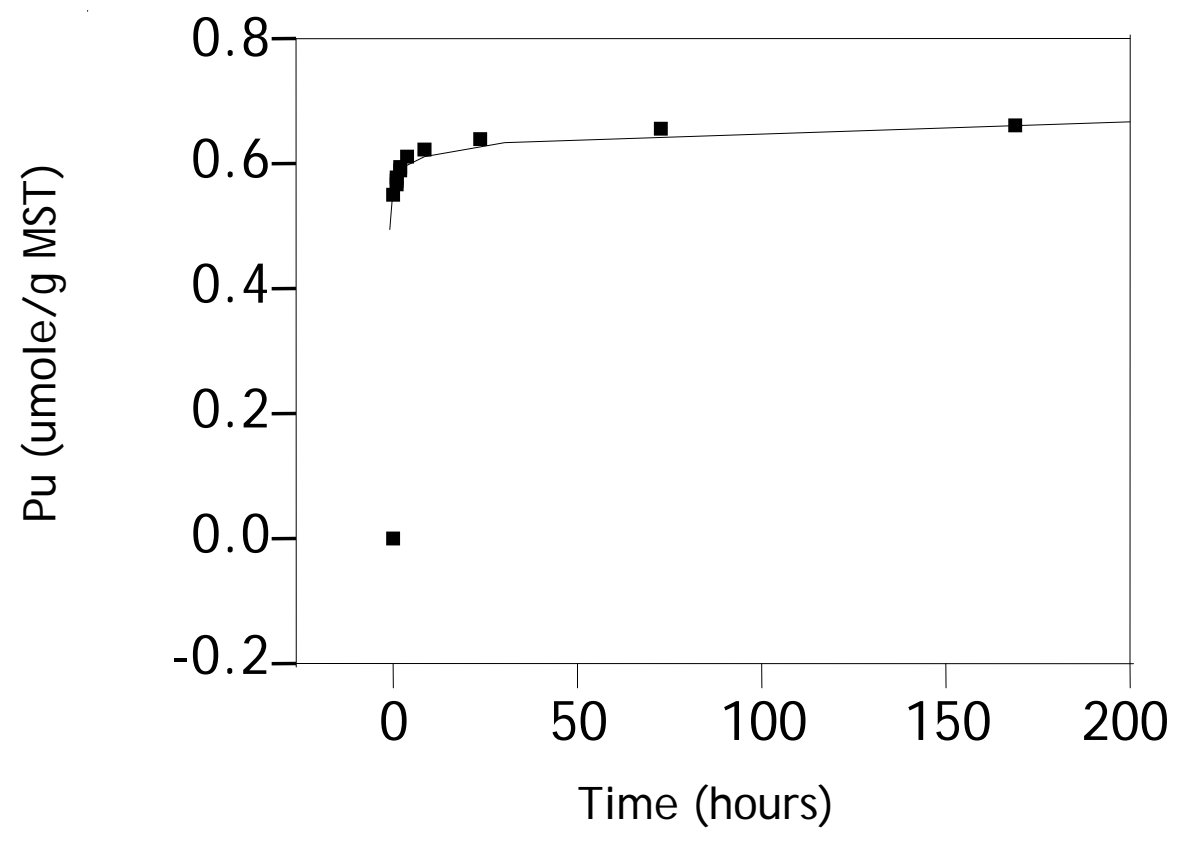

Figure 26. Pu loading on MST at $[\mathrm{Na}]=6 \mathrm{M}, \mathrm{T}=25^{\circ} \mathrm{C}$ and $0.2 \mathrm{~g} / \mathrm{L}$ MST. Filled squares are measured values. Line is predicted values. 


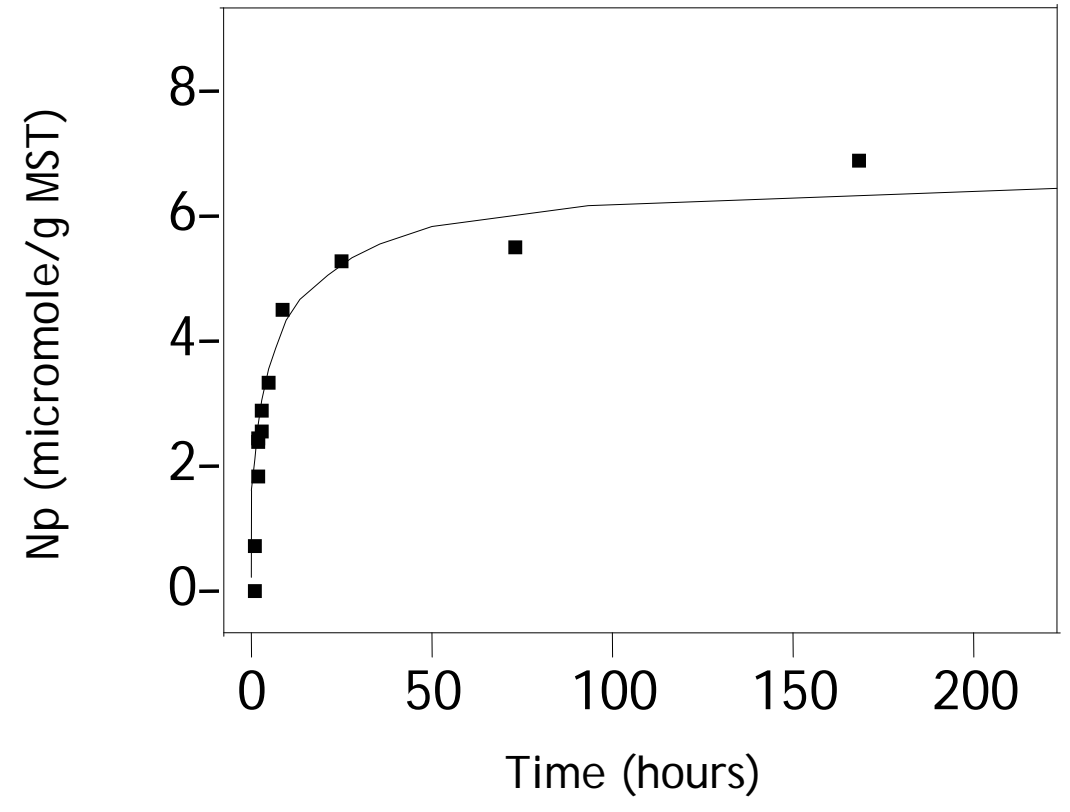

Figure 27. Np loading on MST at $[\mathrm{Na}]=6 \mathrm{M}, \mathrm{T}=25^{\circ} \mathrm{C}$ and $0.2 \mathrm{~g} / \mathrm{L}$ MST. Filled squares are measured values. Line is predicted values.

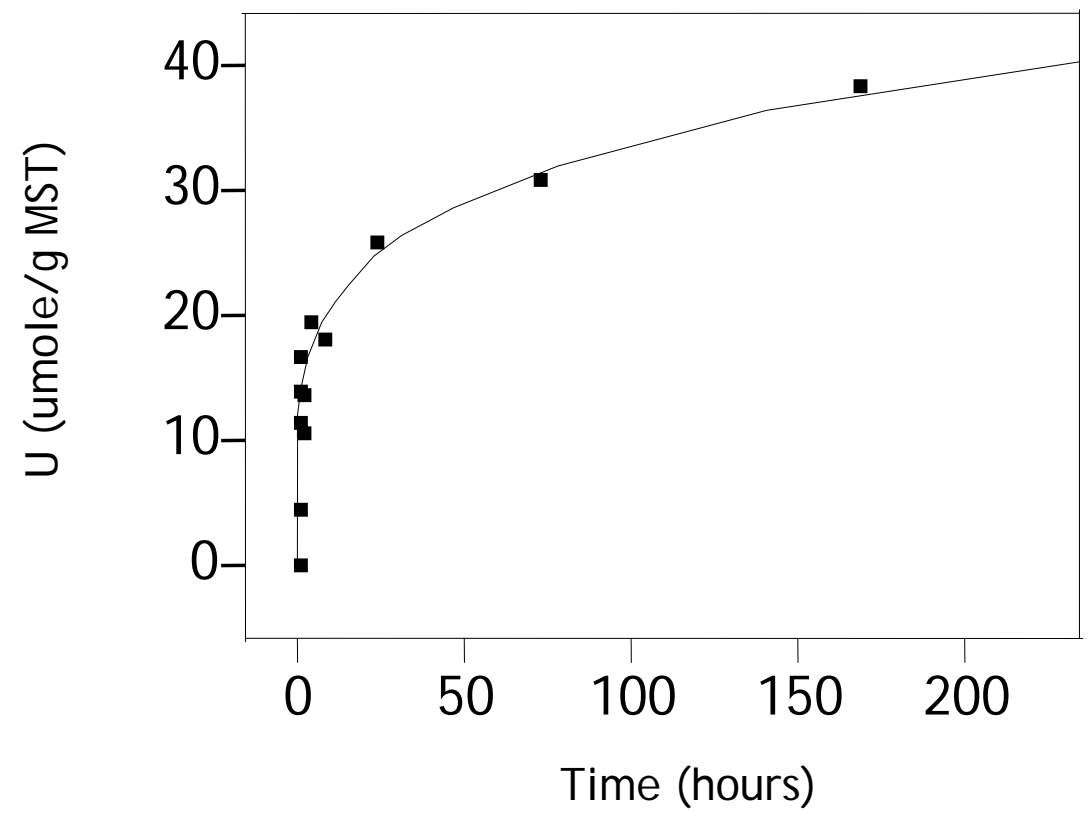

Figure 28. $\mathrm{U}$ loading on MST at $[\mathrm{Na}]=6 \mathrm{M}, \mathrm{T}=25^{\circ} \mathrm{C}$ and $0.2 \mathrm{~g} / \mathrm{L}$ MST. Filled squares are measured values. Line is predicted values. 


\subsection{Conclusions}

A number of laboratory studies have been conducted to determine the influence of mixing and mixing intensity, solution ionic strength, initial sorbate concentrations, temperature, and MST concentration on the rates of sorbate removal by MST in high-level nuclear waste solutions. Of these parameters, initial sorbate concentrations, ionic strength and MST concentration have the greater impact on sorbate removal rates. The lack of a significant influence of mixing and mixing intensity on sorbate removal rates indicates that bulk solution transport is not the rate controlling step in the removal of strontium and actinides over the range of conditions and laboratory-scales investigated. However, bulk solution transport may be a significant parameter upon use of MST in a 1.3 million-gallon waste tank such as that planned for the SCIX program. Thus, SRNL recommends completing the experiments in progress to determine if mixing intensity influences sorption rates under conditions appropriate for the SCIX program. Adsorption models have been developed from these experimental studies that allow prediction of $\mathrm{Sr}, \mathrm{Pu}, \mathrm{Np}$ and $\mathrm{U}$ concentrations as a function of contact time with MST. Fairly good agreement has been observed between the predicted and measured sorbate concentrations in the laboratory-scale test data.

\subsection{References}

1. D. T. Hobbs, M. G. Bronikowski, T. B. Edwards, R. L. Pulmano, "Final Report on Phase III Testing of Monosodium Titanate Adsorption Kinetics", WSRC-TR-99-00134, Rev. 0, May 28, 1999.

2. D. T. Hobbs, R. L. Pulmano, "Phase IV Simulant Testing of Monosodium Titanate Adsorption Kinetics", WSRC-TR-99-00219, Rev. 0, June 29, 1999.

3. D. T. Hobbs, M. S. Blume, H. L. Thacker, "Phase IV Testing of Monosodium Titanate Adsorption with Radioactive Waste", WSRC-TR-99-00286, Rev. 0, September 3, 1999.

4. D. T. Hobbs, M. S. Blume, H. L. Thacker, "Phase V Simulant Testing of Monosodium Titanate Adsorption Kinetics", WSRC-TR-2000-00142, Rev. 0, May 242000.

5. T. B. Peters, S. D. Fink, D. T. Hobbs, M. A. Norato, D. D. Walker, "Demonstration of MST and Permanganate Efficiency on removal of Actinides and Strontium from Savannah River Site High-Level Waste", WSRC-TR-2002-00355, Rev. 0, March 11, 2003.

6. F. F. Fondeur, D. T. Hobbs, S. D. Fink, M. J. Barnes, "Sorption Modeling of Strontium, Plutonium, Uranium and Neptunium Adsorption on Monosodium Titanate", WSRC-TR2003-00180, Rev. 0, May 7, 2003.

7. F. F. Fondeur, D. T. Hobbs, M. J. Barnes, T. B. Peters, S. D. Fink, "Prediction Models for Plutonium, Strontium, Uranium and Neptunium Loading onto Monosodium Titanate (MST)", WSRC-TR-2004-00608, Rev. 0, July 11, 2005.

8. F. F. Fondeur, D. T. Hobbs, M. J. Barnes, T. B. Peters, S. D. Fink, "Dubnin-Astashov Predictions of Elevated Fissile Loading on Monosodium Titanate: Comparison with ARP and SWPF Results", WSRC-TR-2006-00169, Rev. 0, September 26, 2007.

9. Duff, M. C.; Hunter, D. B.; Hobbs, D. T.; Fink, S. D.; Dai, Z.; Bradley, J. P., "Mechanisms of Strontium and Uranium Removal from High-Level Radioactive Waste Simulant Solutions by the Sorbent Monosodium Titanate," Environ. Sci. Technol. 2004, 38(19), 5201 - 5207. 


\section{Appendix A. Test Conditions and Initial Sorbate Concentrations for Adsorption Rate Tests}

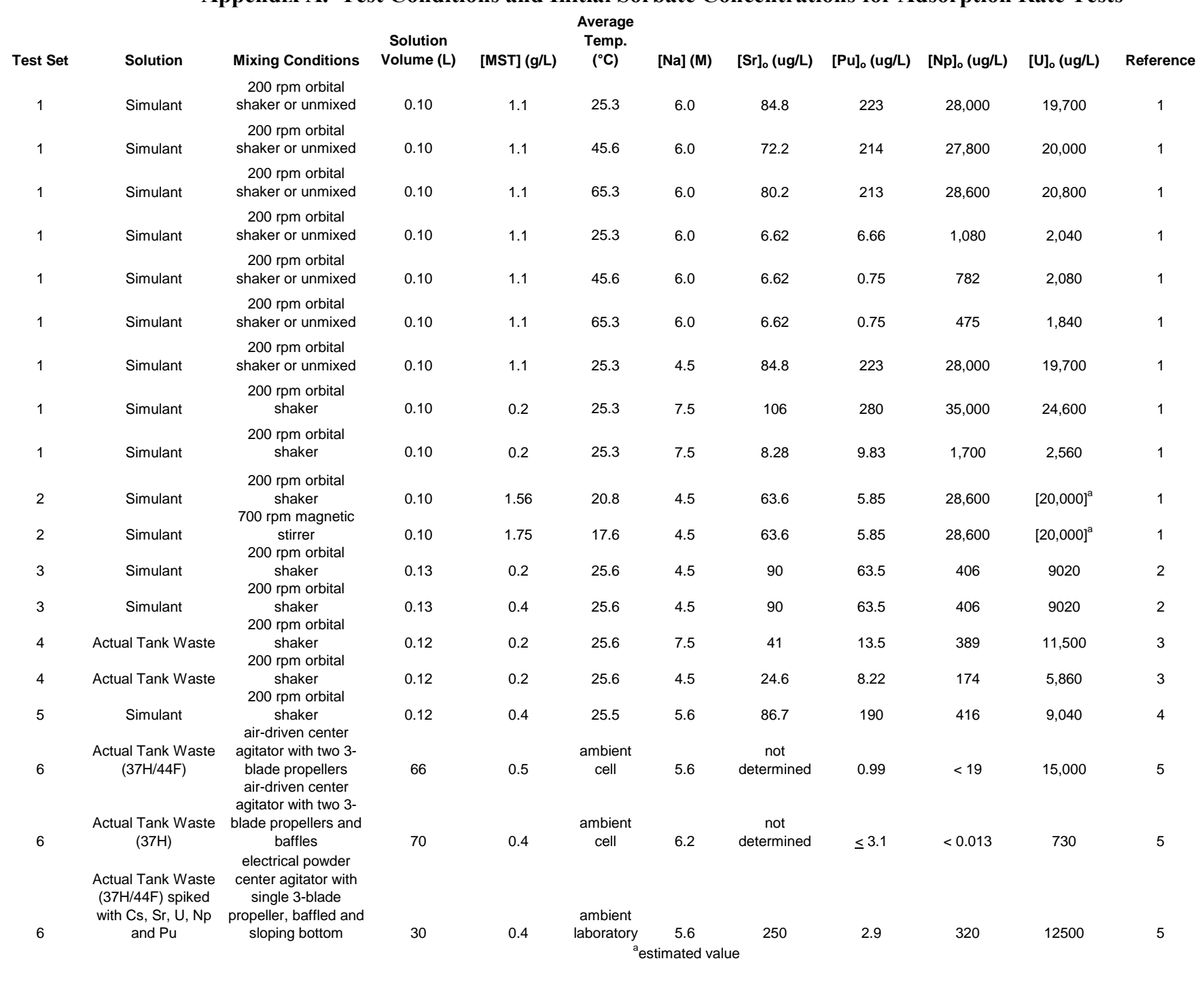


SRNL-STI-2010-00438

Rev. 0 


\section{Distribution:}

S. L. Marra, 773-A

S. D. Fink, 773-A

F. M. Pennebaker, 773-42A

K. M. L. Taylor-Pashow, 773-A

D. T. Hobbs, 773-A

T. B. Peters, 773-42A

F. F. Fondeur, 773-A

R. E. Edwards, 766-H

T. H. Huff, 766-H

M. A. Rios-Armstrong, 766-H

D. J. Martin, 241-152H

E. J. Freed, 704-56H

K. L. Lang, 704-27S 